\title{
THE ECONOMIC EFFECTS OF VARIETIES TECHNOLOGY ON PRODUCTION OF WHITE SUMMER MAIZE IN GHARBIA GOVERNORATE
}

\author{
EYSA, IBRAHIM ELSAID, OMAR AHMAD BADR, \\ WAGIH ABD-EL-AZIZ FARRAG and NAGLAA ELSAID AHMED SHABAN
}

Agricultural Economics Research Institute, Agricultural Research Centre; ARC/Egypt

(Manuscript received 10 September 2018)

\begin{abstract}
$\mathrm{M}$ aize is one of the most important cereal crops in Egypt where used in animal nutrition. The research problem: with studying the economic impacts for using varieties technology of maize in Gharbia Governorate, the most of farmers cultivate many of available varieties without looking efficiency of productivity, her, we asked what is the impact application of technological methods of modern varieties of maize in Gharbia Governorate. The aim of the research: the impact of shifting the supply function, and appreciate efficiency of productivity and economic, and access to the best map of the study crop. By studying the economic impact of the cultivation of modern varieties of white maize on shifting the supply function in Gharbia governorate: with replace single hybrid (haitek 2030) instead of single hybrid: $10,130,128,323$, it has led to shift the supply function to the right, which leads to increase the production by about 30 thousand ardebs assuming cultivation half of the area under maize in Gharbia governorate for the season 2017, its value reached about 13.5 million pounds. As for the triple varieties, it showed that by replacing the variety triple hybrid (321) instead of the triple hybrid varieties 310, 324, 311, its productivity reached about 24.6 ardebs / feddan of 2017, the production from $50 \%$ of the total area of maize in governorate increase with about 40 thousand ardebs, its value about 18 million pounds, and thus the cultivation of the total area of the maize crop in Gharbia governorate with single (haitc 2030) and triple 321 increase the production by about 70 thousand ardebs, its value about 31.5 million pounds, thus recommends with cultivate the two varieties in Gharbia governorate . With studying the economic efficiency of hybrid single white maize of seed component of the varieties mentioned that the value of the marginal product reached about 576.0, 369.9, 841.5, 399.15 pounds, while the price of each element of about 58.06, 38.58, 54.97, 30.0 pounds respectively, that means there is an economic efficiency seed element Where the value of the marginal product of the element is greater than its price in the market. But it is possible increase this efficiency until the value marginal product equals the price of element in the market. The economic efficiency of the triple hybrid of white maize of seed component of the items indicate that the value of the marginal product reached about $445.95,147.6,312.3,606.15 \mathrm{~L}$. E , while the price of each component reached about 20.9, 20.55, 20.45, 19.24 pounds respectively, indicate that the seed component has achieved the Efficiency Where the value of marginal product of seed component greater than its price, but it is still possible to increase the efficiency until the value of the marginal product of element equal price in the market. By studying some of the economic measures of single white maize: the percentage of the profit margin of the producer reached about $43.66 \%, 44.51 \%, 43.97 \%$, 43.97\%, 35.26\% respectively, as the rate of economic efficiency of the single varieties
\end{abstract}


reached about $177.51 \%, 180.20 \%, 178.47 \%, 154.47 \%$ respectively, It is possible arrange single maize varieties, according to the percentage the proportion of the profit margin and the rate of Economic efficiency as follows: single Hybrid (10), single hybrid (130), single hybrid (2030), single hybrid (128) respectively. As for the triple hybrid of white maize: the percentage of the profit margin of the producer estimated about $42.20 \%, 22.32 \%, 38.55 \%, 38.61 \%$ respectively, and the rate of economic efficiency in triple varieties reached about $173.02 \%, 128.73 \%, 162.72 \%$, $162.90 \%$ respectively. So it can arrange the triple maize varieties, where the percentage of the profit margin and the rate of economic efficiency as follows: triple hybrid (321), triple hybrid (311), triple hybrid (324), triple hybrid (310) respectively.

\section{The recommendations:}

1- Replacing the single hybrid maize variety (haitc 2030) instead of the lower other varieties, where it has high productivity and has an economic efficiency in Gharbia Governorate.

2- Replacing the triple hybrid maize variety ( 321 ) instead of the lower other varieties, where it has high productivity and has an economic efficiency in Gharbia Governorate.

3- The producer company's of white maize seeds in Egypt, its must be carrying out the recommendations of this research. 


\title{
الآثار الاقتصادية لتكنولوجيا الأصناف الحديثة على إنتاج محصول الذرة الثامية البيضاء الصيفي في محافظة الغربية الأبئية
}

\author{
إبراهيم السيب عيسى ،عمر أحمد بلر \\ وجيه عبد العزيز فراج ، نجلاء السيد أحمد شعبان البران \\ معهج بحوث الإقتصاد الزراعي - مركز البحوث الزراعية ـ دقي - جيزة . \\ الملخص
}

يعتبر محصول الذرة الثامية من أهم محاصيل الحبوب الغذائية في مصر ، لذا فإن الدولة تولى

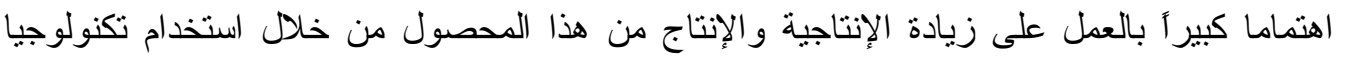

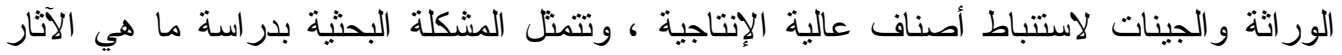
الاقتصادية المترنبة على استخدام تكنولوجيا الأصناف على محصول الذرة الثنامية في محافظة الغربية،

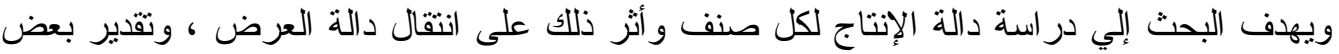

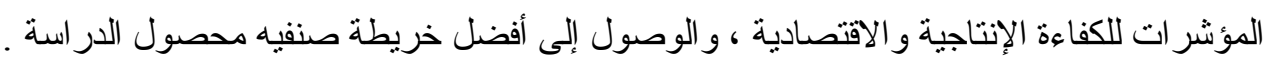

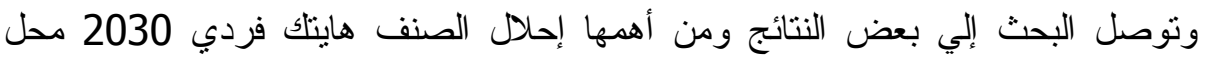
الأصناف هجين فردي 10 ، 130 ، 128 ، 323 و المتفوق عليها إحصائيا محل هذه الأصناف

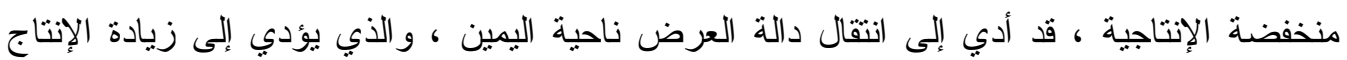

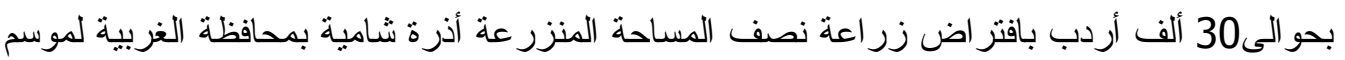

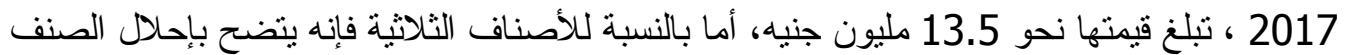

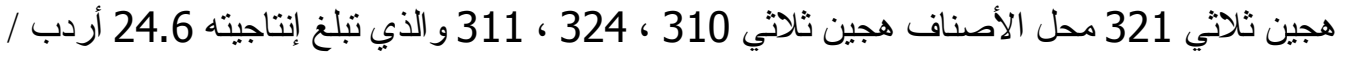

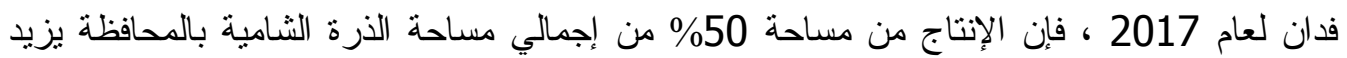
بحو الي 40 ألف أردب ، تبلغ قيمتها نحو 18 مليون جنيه ، وبذللك فإن زراعة من الإنة المساحة الإجمالية لمحصول الذرة الثامية بالمحافظة بالصنفين الفردي هايتك 2030 ، و الثناثي 321 يزيد الإنتاج بنحو 70 ألف أردب، تبلغ قيمتها حو الي 31.5 مليون جنيه.

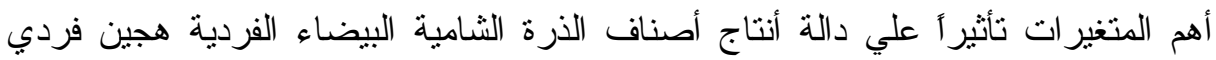

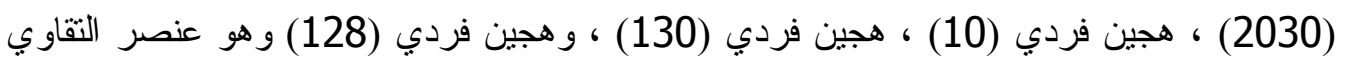

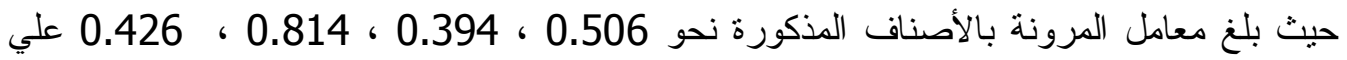
الترتيب ، وبدر اسة الكفاءة الإقتصادية لعنصر التقاوي بالأصناف المذكورة تبين أن فيمة الناتج الحدي

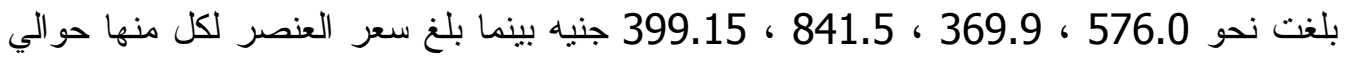

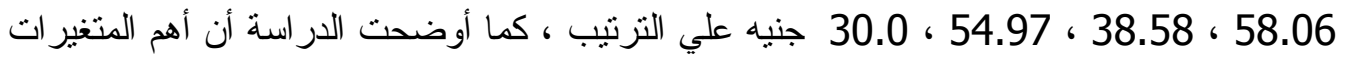

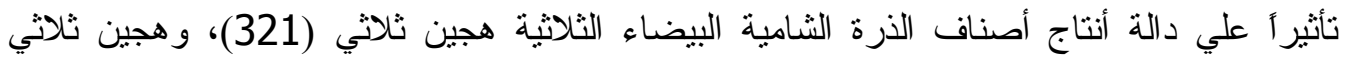

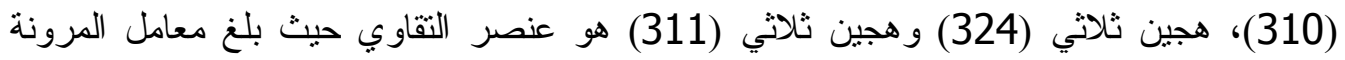

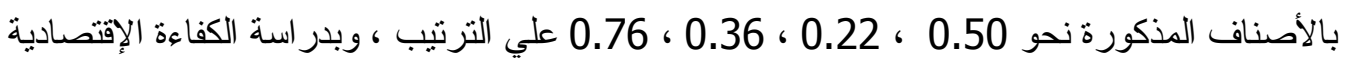

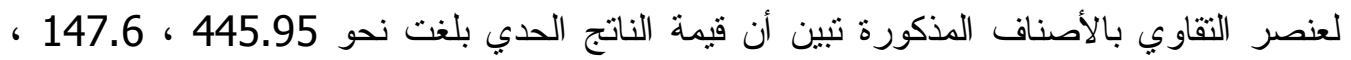
312.3 ، 606.15 جنيه لكل صنف علي الترتيب ، بينما بلغ سعر العنصر لكل منها حوالي 20.9 ، 20.9

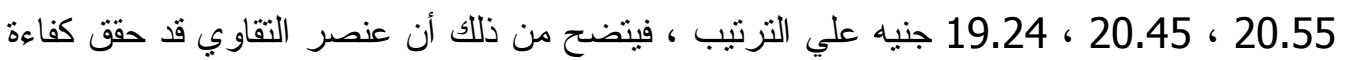


اقتصادية حيث بلغت قيمة الناتج الحدي لعنصر الثقاوي أكبر من سعر العنصر ولكن لازال بالإمكان

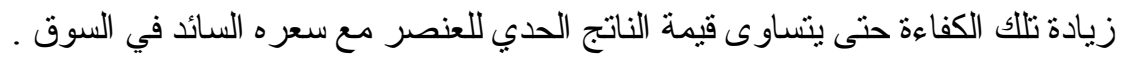
وبدر اسة بعض ألمقاييس الإقتصادية لأصناف الذرة الثامية البيضاء الفردية التالية: هجين

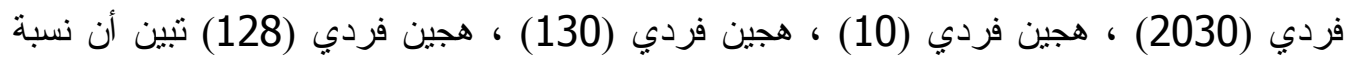

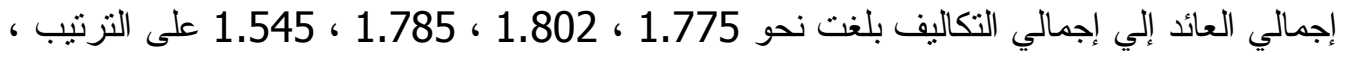
كما بلغ عائد الجنيه المستثمر في تلك الأصناف نحو

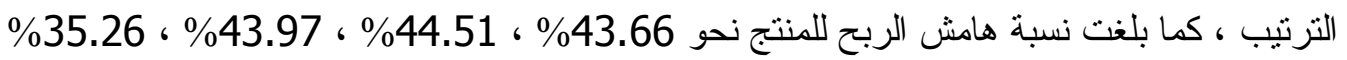
على الترتيب ، كما بلغ معدل الكفاءة الإقتصادية في الأصناف الفردية نحو 178. 177.51 ،

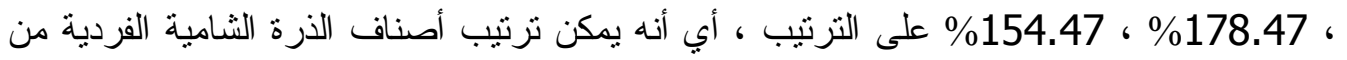

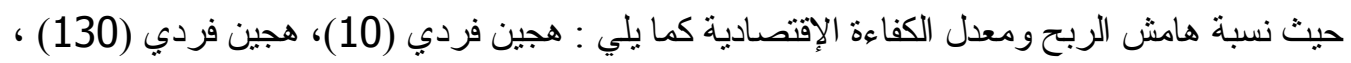

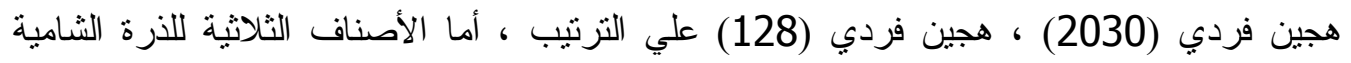
البيضاء (هجين ثلاثي (321) ، هجين ثلاثي (310) ، هجين ثلاثي (124) (324) ، هجين ثثلثي (311) )

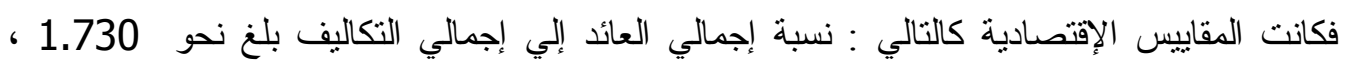

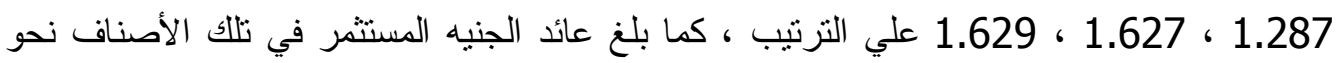

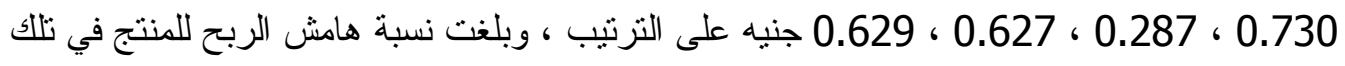

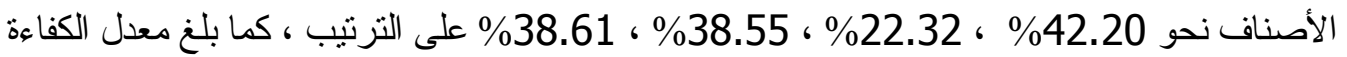

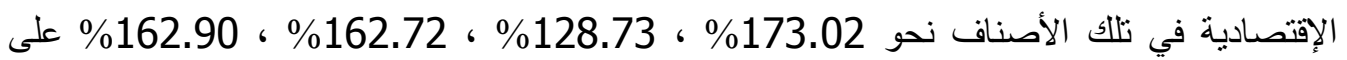

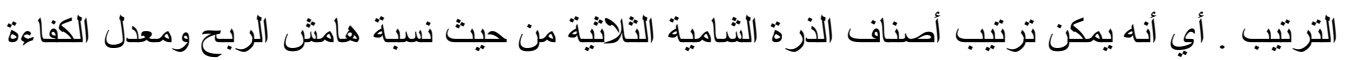

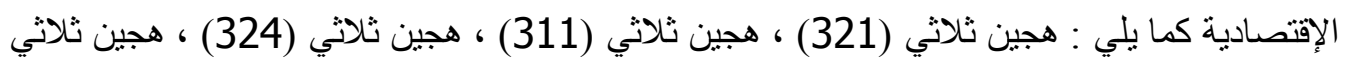

\section{المقدمة}

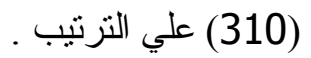

يعتبر محصول الذرة الثامية من محاصيل الحبوب الهامة في مصر ، حيث انه يمكن استخدامه في صناعة الأعلاف ، علاوة على انه يدخل في العديد من الصناعات الغذائية منل زيت الذرة و النشا و الكحول و الخميرة و الجلوكوز ، حيث بلغ متوسط مساحة الذرة بمحافظة الغربية حو الي 96.85

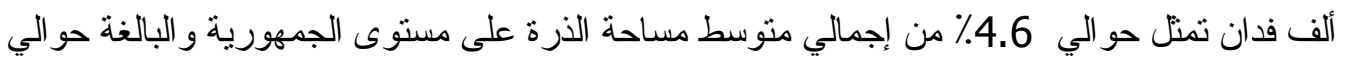
2098 ألف فدان كمتوسط للفترة ( 2017-2013) ، كما بل بلغت الإنتاجية الفدانية للذرة في المحافظة حو الي 3.418 طن تمنل نحو 103.9 \% من إجمالي الإنتاجية الفدانية للذرة على مستوى الجمهورية

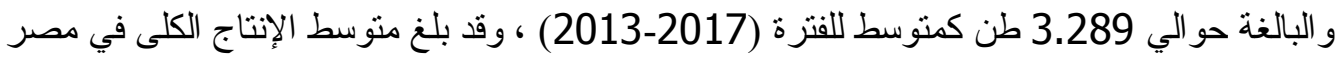

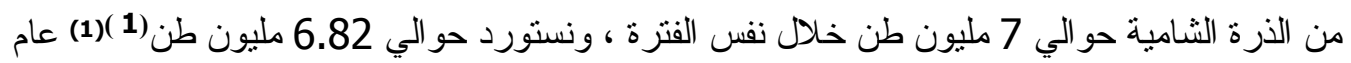
2016

\section{مشكلة البحث}

على الرغم من الزيادة في إنتاج محاصيل الحبوب بصفة عامة، ومحصول الذرة الثامية بصفة

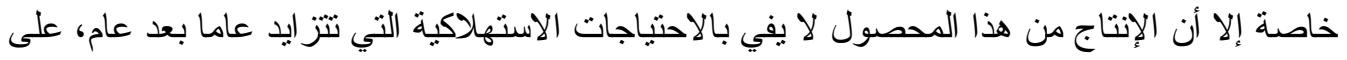

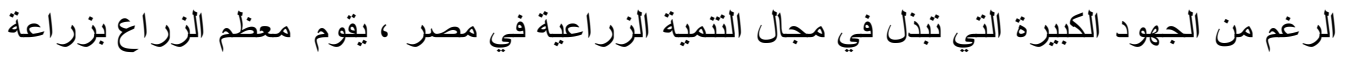

(1) وزارة الزراعة واستصلاح الأر اضي_ قطاع الثئون الإقتصادية ـ نشرة الميزان الغذائي ، عام 
العديد من الأصناف المتاحة دون النظر إلي جدارتها الإنتاجية ، و بلغت نسبة الاكتفاء الذاتي لمحصول

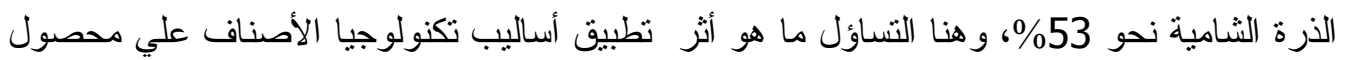
الذرة الشامية في محافظة الغربية .

\section{هدف البحث}

يتبلور هدف البحث في بيان أثر تكنولوجيا الأصناف الحديثة على الناتج من محصول الذرة الثامية،

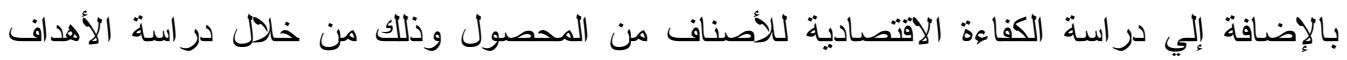

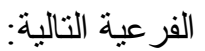

1. در اسة الأهمية النسبية للمساحة و الإتتاجية و الإنتاج لأهم الأصناف لمحصول الدر اسة في محافظة

$$
\text { الغربية خلال الفترة (2017-2013). }
$$

2. دراسة دالة الإتتاج لنقدير أثز تكنولوجيا الأصناف على كمية الناتج من محصول الدراسة عام

3. در اسة مدى تأثنير تكنولوجيا الأصناف على انتقال دالة العرض لمحصول الدر اسة لعام 2017.

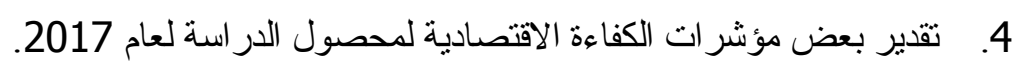
الطريقة البحثية ومصادر البيانات

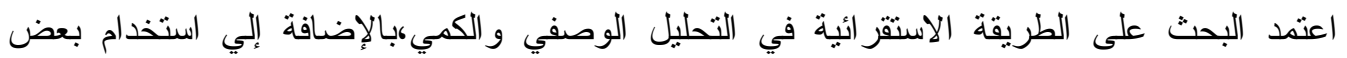

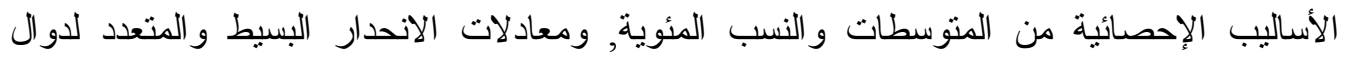

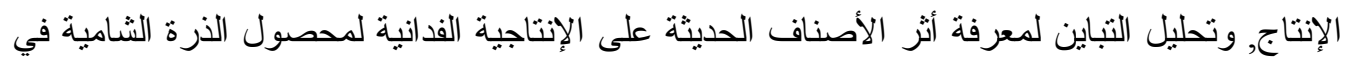
محافظة الغربية, وعمل خريطة صنفيه لهذا المحصول كما نم إستخدام بعض النماذج الإحصائية منل الإنل

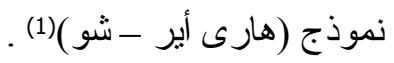

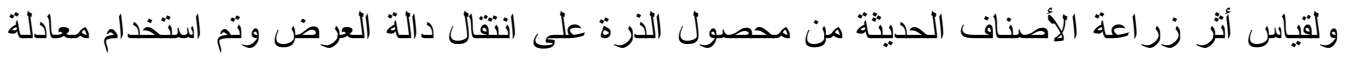
(هاري اير - و إدو ارد شو) في قياس درجة انتقال دالة العرض الناتج عن التغير التكنولوجى و المتمثل في إدخال أصناف جديدة . $\mathrm{K}=\mathrm{E}[(1-(\mathrm{YU} \times \mathrm{FU}) /(\mathrm{YA} \times \mathrm{FA})) \mathrm{PA}] \times 100$

=YA FA
= معامل الإنتقال النسبي في العرض = K

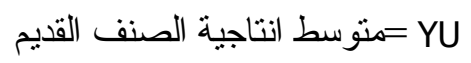
= FU = النسبة المئوية لمساحة الصنف الاحديث بالذ سبة لم ساحة الأصناف المزرو عة بالمدصول علي مستوي محافظة الغربية .

(1) Harry. Ayer and G Edward Schuh, Social Rates of Return and other Aspects of Agricultural Research, The case of Cotton Research in Sao Paulo, Barazil, American Journal of Agricultural Economics Vol. 54 No 4 part 1, 1972 P. 560 .

$$
\begin{aligned}
& \text { (2) مديرية الزر اعة بالغربية - سجلات إدارة الإحصاء - بيانات غير منشورة . }
\end{aligned}
$$

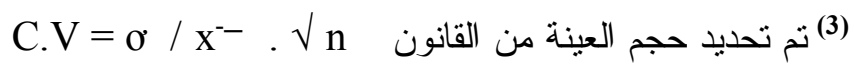

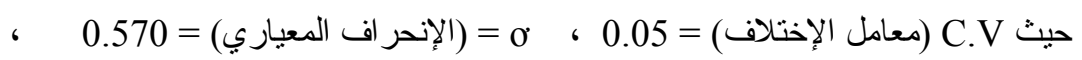

$$
\begin{aligned}
& 0.672=x^{-}
\end{aligned}
$$


وقد اعتمد البحث على البيانات الثانوية المنشورة وغير المنشورة من وزارة الزراعة

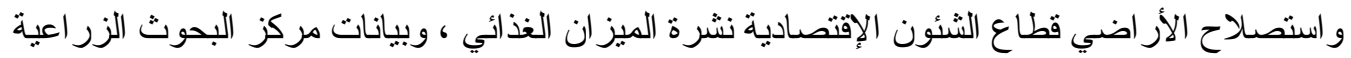

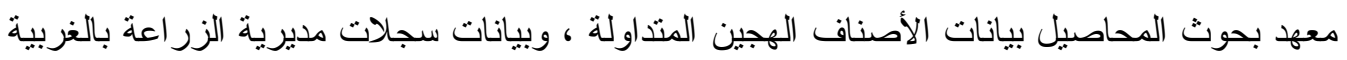

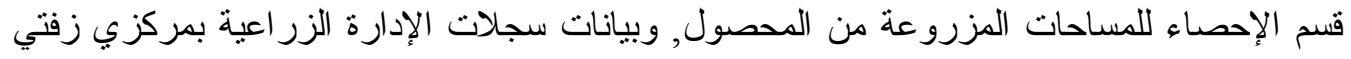

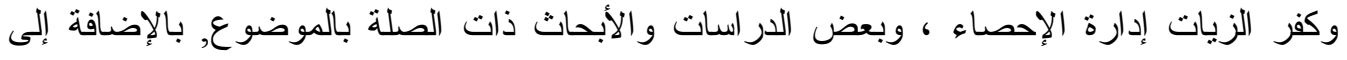

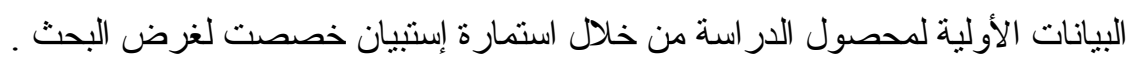
إختيار عينة الدراسة

تم إختيار مركزي زفني وكفر الزيات بمحافظة الغربية وفقا للأهمية النسبية لمساحة الذرة الذهاء

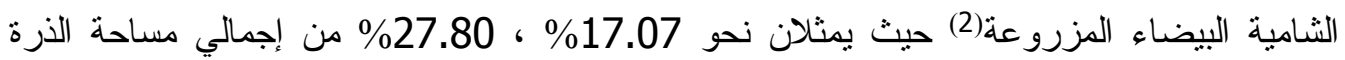

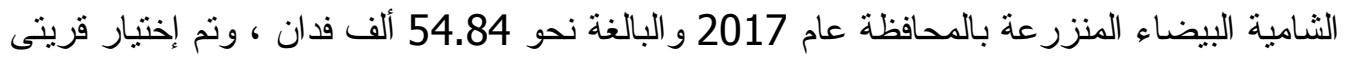
شرشابة وسنباط بمركز زفتي، وقريتى أبو الغر ومنشأة سليمان بمركز كفر الزيات وفقا للأهمية النسبية

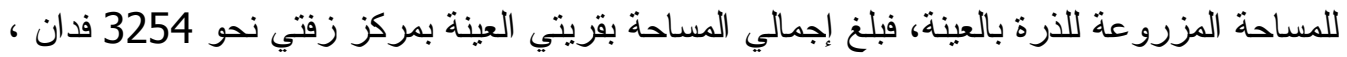

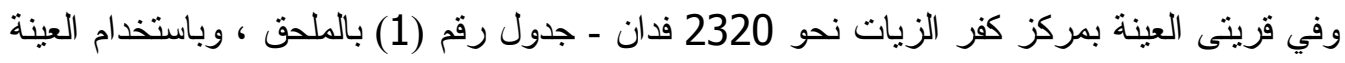

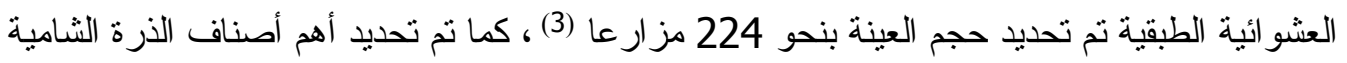
البيضاء المزروعة بمحافظة الغربية - جدول رقم (2) بالملحق، كما تم تحديد عدد الحائزين المختارين

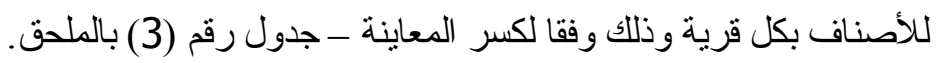

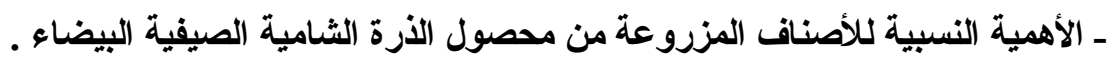
1- الأهمية النسبية للأصناف الفردية .

بدر اسة البيانات بالجدول رقم (1) نبين أن أهم الأصناف الفردية المزروعة من محصول الذرة الثنامية

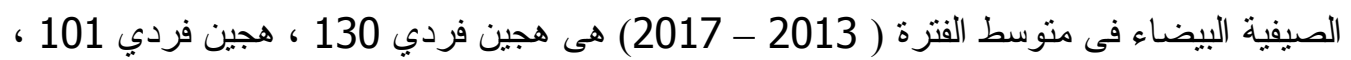
هجين فردي 10 ، هجين فردي 128 ، هجين فردي 2030 هايتك حيث تقدر المساحة المزروعة بتلك

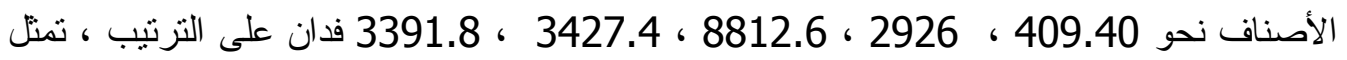

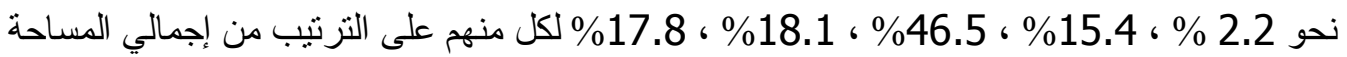

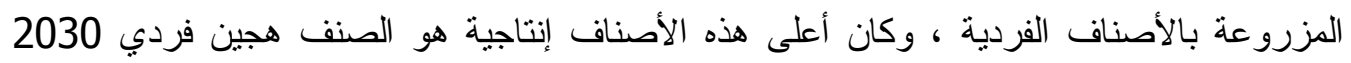

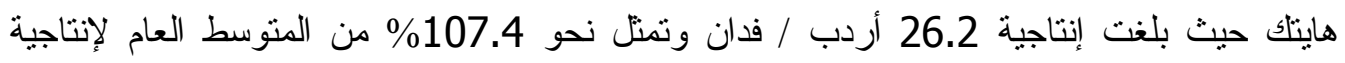

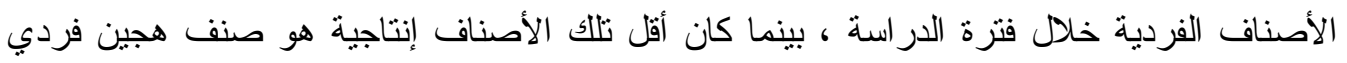
101، هجين فردي 128 حيث قدرت إنتاجيتهما بنحو 22 أردب/فدان، يمثل كل منهما نحو

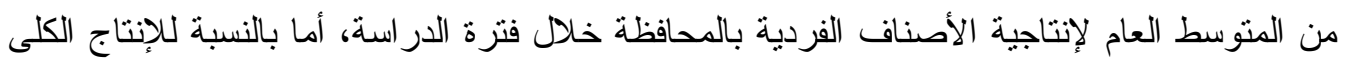

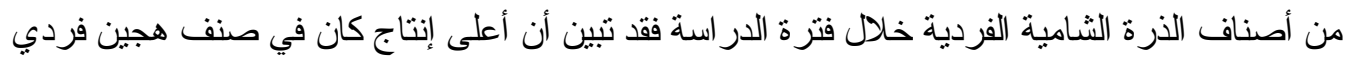
10 حيث بلغ نحو 224 ألف أردب تمنل نحو 48.5 \% من إجمالي إنتاج الأصناف الفردية، بينما كان

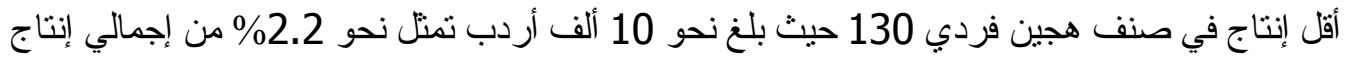
الأصناف الفردية و البالغ نحو 462 ألف أردب وذللك خلال منو سط فترة الدر اسة . 
جدول رقم (1): الأهمية النسبية للأصناف الفردية المزروعة بمحصول الذرة الثامية البيضاء بمحافظة الغربية متوسط للفترة (2013-2017)

\begin{tabular}{|c|c|c|c|c|c|c|}
\hline إنتاج الإنتاجف إلجمالي & إنتاجية الصنو الصنف & 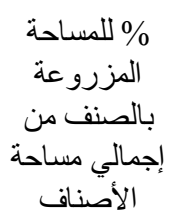 & ألكإلتئي & (ألإردب) & المساحة & الصنف \\
\hline 2.2 & 100 & 2.2 & 10 & 24.4 & 409.4 & هـ ف 130 \\
\hline 13.9 & 90.2 & 15.4 & 64 & 22.0 & 2926.0 & هـ ف 101 \\
\hline 48.5 & 104.1 & 46.5 & 224 & 25.4 & 8812.6 & هـ ف 10 \\
\hline 16.2 & 90.2 & 18.1 & 75 & 22.0 & 3427.4 & هـف 128 \\
\hline 19.3 & 107.4 & 17.8 & 89 & 26.2 & 3391.8 & هـ فايتك 2030 هـ \\
\hline 100 & --- & 100 & 462 & 24.4 & 18967.2 & الإجمالي \\
\hline
\end{tabular}

(*) منت سط الإنتاجية المرجح للمساحة المصدر : مديرية الزر اعة بالغربية ـ سجلات إدارة الإحصاء - بيانات غير منشورة . 2- الأهمية النسبية للأصناف الثلاثية

تنين من در اسة بيانات الجدول رقم (2) أن أهم الأصناف الثناثية المزروعة من محصول الذرة الثامية

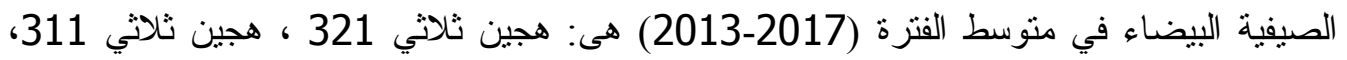

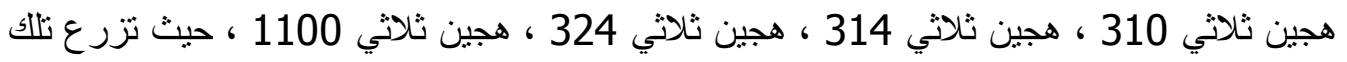

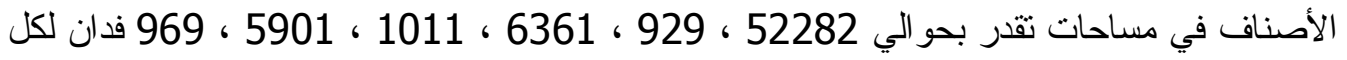
منهم على الترنيب، تمنل نحو 77.5\% ، 1.4\% ،

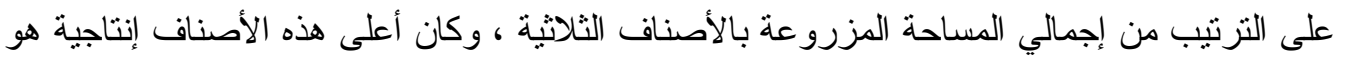

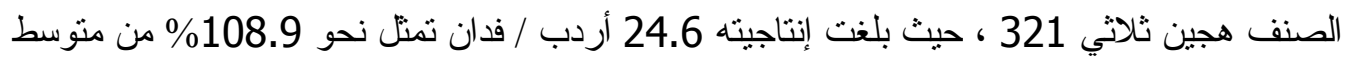

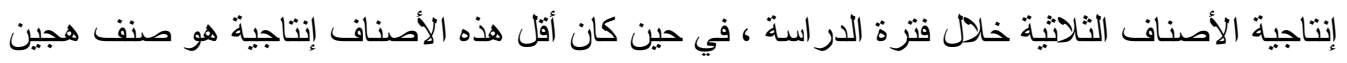

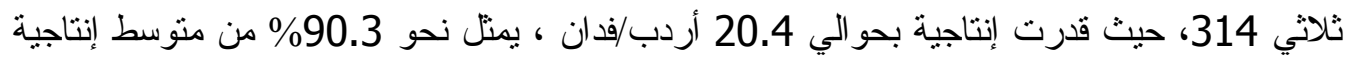

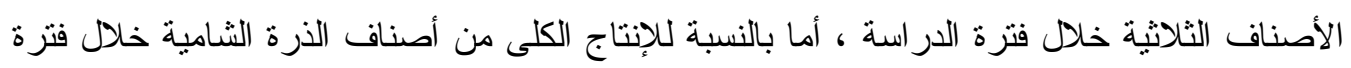

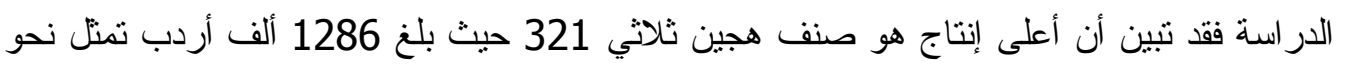

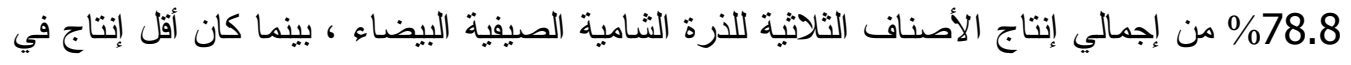

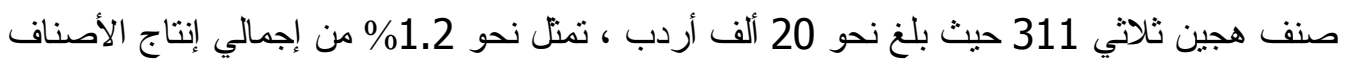

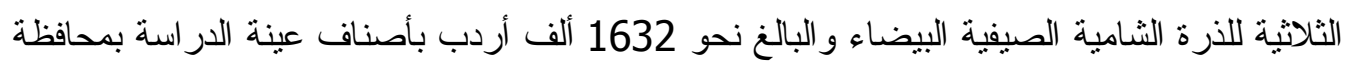

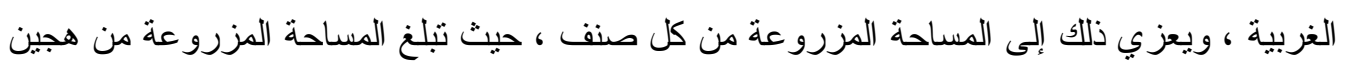
ثلاثي 321 نحو 52282 فدان ، بينما تبلغ المساحة المزرو عة من صنف هجئ كين ثلاثي 311 نحو 929 
جدول رقم (2): الأهمية النسبية للأصناف الثلاثية المزروعة من محصول

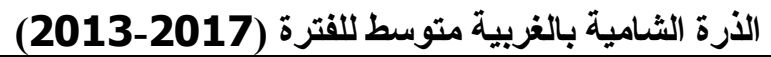

\begin{tabular}{|c|c|c|c|c|c|}
\hline 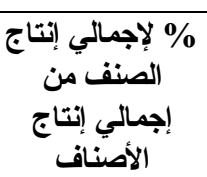 & من الجزروعة بالصئفة مساحة & ألإلفتاج أردب) & (ألردباجية & (فلمان) & الصنف \\
\hline 78.8 & 77.5 & 1286 & 24.6 & 52282 & هـ ث 321 \\
\hline 1.2 & 1.4 & 20 & 21.2 & 929 & هـ ث 311 \\
\hline 9.2 & 9.4 & 150 & 23.6 & 6361 & هـ ث 310 \\
\hline 1.3 & 1.5 & 21 & 20.4 & 1011 & هـ ث 314 \\
\hline 8.1 & 8.7 & 132 & 22.4 & 5901 & هـ ث 324 \\
\hline 1.4 & 1.4 & 23 & 23.4 & 969 & هـ ث 1100 \\
\hline 100 & 100 & 1632 & 22.6 & 67453 & المرجح للمساحة الإتاجية \\
\hline
\end{tabular}

المصدر : مديرية الزر اعة بالغربية ـ سجلات إدارة الإحصاء - بيانات غبر منشورة .

ـ تحليل التباين لأثر تكنولوجيا الأصناف على الإتتاجية الفدانية للأرة الشامية الصيفية البيضاء:

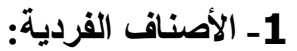
وقد اتضح من جدول رقم (3) أنه بإجر اء تحليل التباين لأهم الأصناف الفردية من محصول الذرة الثامية في محافظة الغربية خلال الفترة ( 2013 ـ 2017 ) تبين من خلال قيمة F المحسوبة وجود

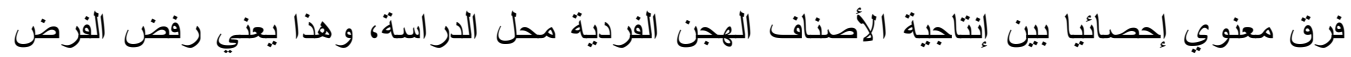
العدم الخاص بتساوي الإنتاجية للأصناف الهجن الفردية وبناءأ عليه تم إجراء التحليل المقارن بين متوسطات الإنتاجية للأصناف الخمسة المبينة بالجدول رقم (4) من خلال تقدير أقل فرق معنوي

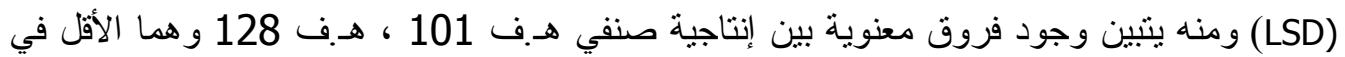

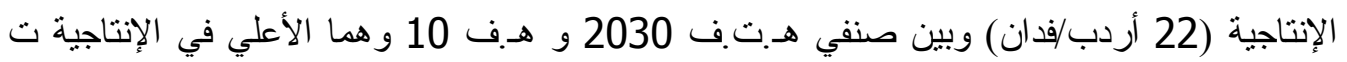

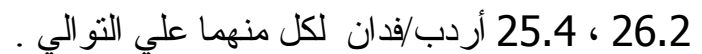
ولم تتبت معنوية الفروق بين إنتاجية الأصناف (هـ.ت فـ 2030 ، هـ.ف 130 ، هـ.ف 10) و التي تبلغ

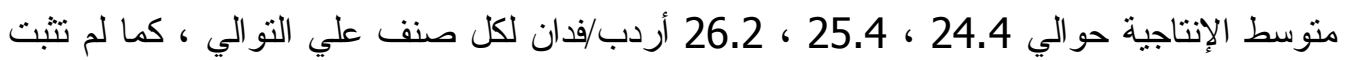
معنوية الفروق بين إنتاجية صنفي (هـ.ف 101 ، هـ.ف 128) ، 24.

جدول رقم (3) : تحليل التباين للأصناف الفردية المزروعة بمحصول

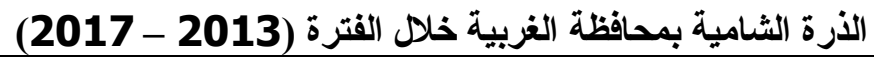

\begin{tabular}{|c|c|c|c|c|}
\hline & $\begin{array}{c}\text { Some of } \\
\text { squares }\end{array}$ & df & $\begin{array}{c}\text { Mean } \\
\text { squares }\end{array}$ & F \\
\hline $\begin{array}{c}\text { Between } \\
\text { groups }\end{array}$ & 74.8 & 4 & 18.7 & $3.14^{* *}$ \\
\hline Within groups & 119.2 & 20 & 5.96 & \\
\hline total & 194.0 & 24 & & \\
\hline
\end{tabular}

(1) (المصدر : جمعت وحسبت من جدول رقم 
جدول رقم (4) : اختبار ( L. S . D ) لأهم الأصناف الفردية المزروعة بمحصول الأرة الثامية بمحافظة الغربية خلا الفترة (

\begin{tabular}{|c|c|c|c|c|c|c|}
\hline $\begin{array}{l}\text { هـ } 2030 \\
\end{array}$ & هـ فـ10 & هـ ــ130 & هـ فـ & هـ ف. & & \multirow[t]{2}{*}{ الأصناف } \\
\hline 26.2 & 25.4 & 24.4 & 22 & 22 & المتوسط & \\
\hline \multirow[t]{5}{*}{ - } & 0.8 & 1.8 & ${ }^{* *} 4.2$ & ${ }^{* *} 4.2$ & 26.2 & هـ ـ.ت. ف 2030 \\
\hline & - & 1.0 & ${ }^{* *} 3.4$ & ${ }^{* *} 3.4$ & 25.4 & هـ ـ ف 10 \\
\hline & & - & 2.4 & 2.4 & 24.4 & هـ ـ. ف 130 \\
\hline & & & - & 0.0 & 22.1 & هـ ـ. ف 128 \\
\hline & & & & - & 22.0 & هـ ـف 101 \\
\hline
\end{tabular}

المصدر: جمعت وحسبت من جدول رقم (1 ، 3)

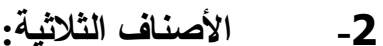

وقد اتضح من جدول رقم (5) أنه بإجر اء تحليل التباين لأهم الأصناف الثناثية من محصول الذرة

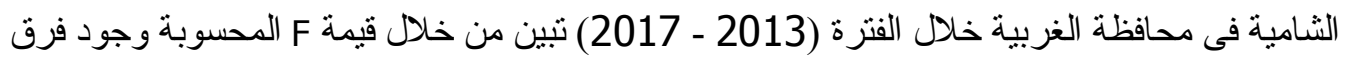

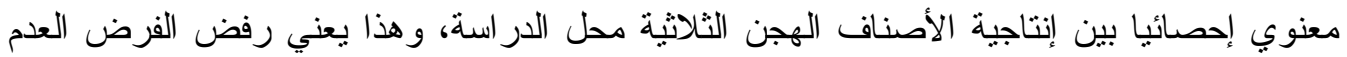
الخاص بتساوي الإنتاجية للأصناف الهجن الثلاثية وبناءأ عليه نت إجر اء التحليل المقارن بين منوسطات

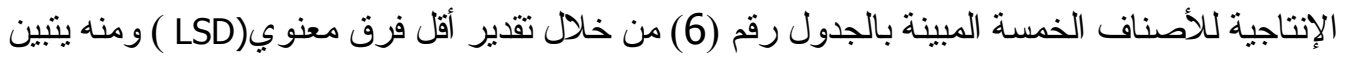
وجود فروق معنوية بين إنتاجية صنفي هـ.ث 314 ، هـ.ث 311 ، هـ هـث 324 هـ 324 وهم الأقل في الإنتاجية

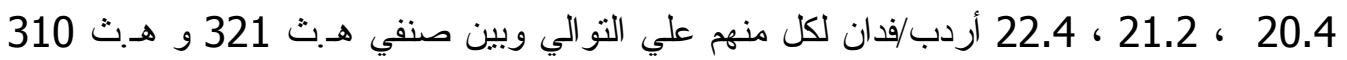

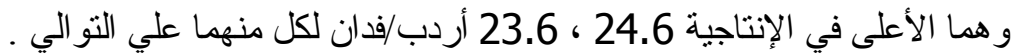

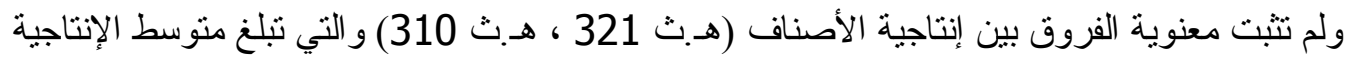
حو الي 24.6 ، 23.6 أردب/فدان لكل صنف علي التو الي، كما لم تنتبت معنوية الفروق بين إنتاجية

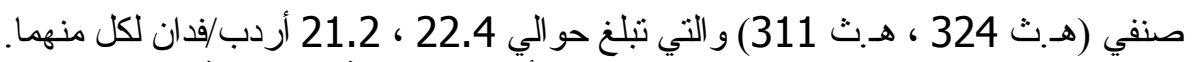

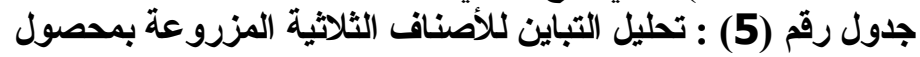

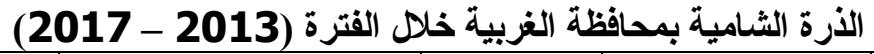

\begin{tabular}{|c|c|c|c|c|}
\hline & Some of squares & df & $\begin{array}{c}\text { Mean } \\
\text { squares }\end{array}$ & $\mathbf{F}$ \\
\hline $\begin{array}{c}\text { Between } \\
\text { groups }\end{array}$ & 58.56 & 4 & 14.64 & $3.978^{* *}$ \\
\hline Within groups & 73.6 & 20 & 3.68 & \\
\hline total & 132.16 & 24 & & \\
\hline
\end{tabular}

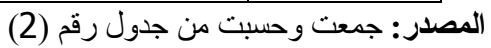

جدول رقم (6) : اختبار (2. S . D ) لأهم الأصناف الثلاثية المزروعة بمحصول

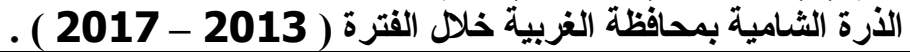

\begin{tabular}{|c|c|c|c|c|c|c|}
\hline هـ .ث 321 & هـ .ث 310 & هـ .ث 324 & هـ .ث 311 & هـ .ث 314 & & \multirow{2}{*}{ الأصناف } \\
\hline 24.6 & 23.6 & 22.4 & 21.2 & 20.4 & المتوسط & \\
\hline \multirow[t]{5}{*}{-} & 1.0 & 2.2 & **3.4 & ${ }^{* *} 4.2$ & 24.6 & هـ . ث 321 \\
\hline & - & 1.2 & 2.4 & ${ }^{* *} 3.2$ & 23.6 & هـ . ث 310 \\
\hline & & - & 1.2 & 2.0 & 22.4 & هـ . ث 324 \\
\hline & & & - & 0.8 & 21.2 & هـ .ث ث 311 \\
\hline & & & & - & 20.4 & هـ . ث 314 \\
\hline
\end{tabular}

الدصدر: جمعت وحسبت من جدول رقم (2 ، 5 ) 
ـ الأثر الإقتصادى لزر اعة الأصناف الفردية و الثلاثية الحديثة على إنتقال دالة العرض لمحصول الذرة الثامية بالغربية.

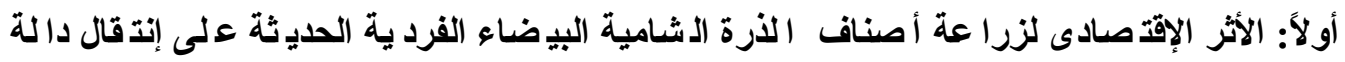

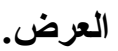

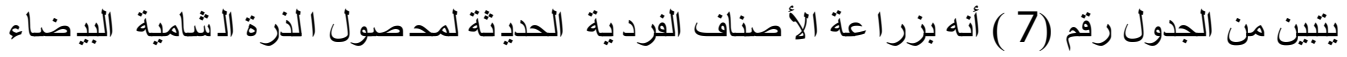

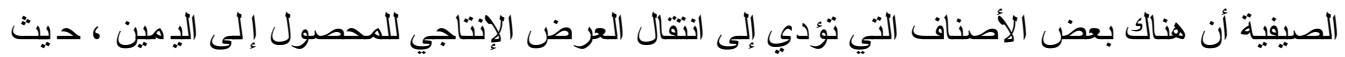

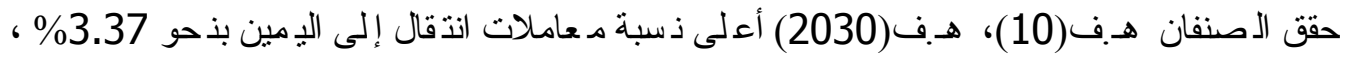

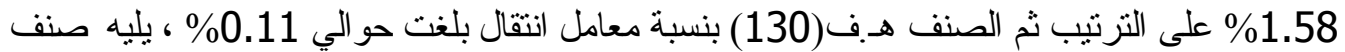

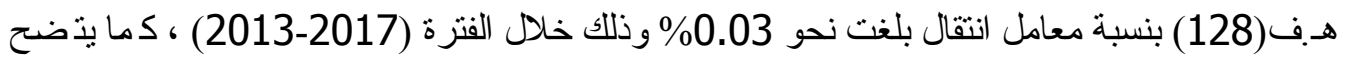

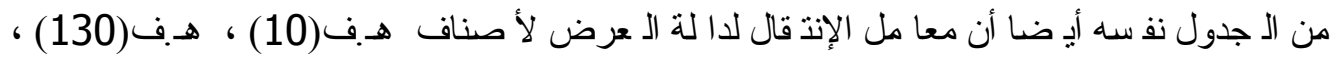

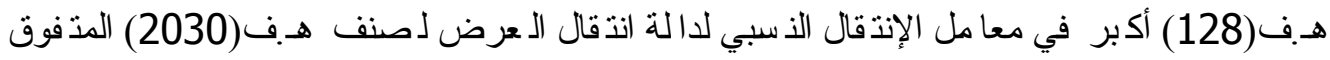

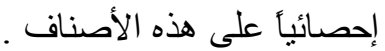

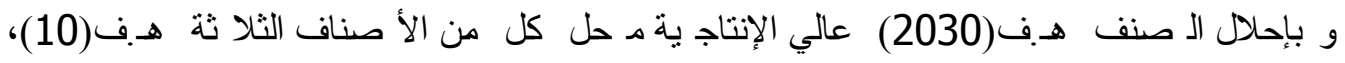

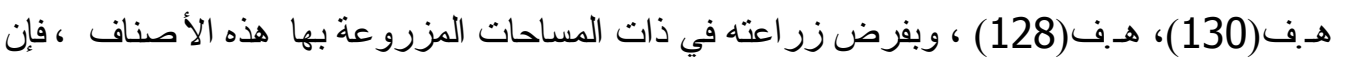

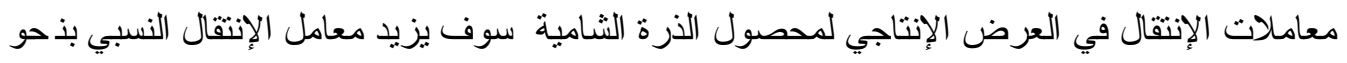

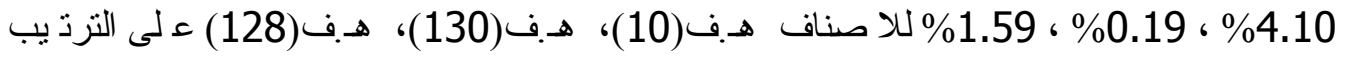

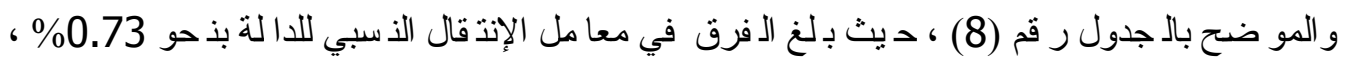

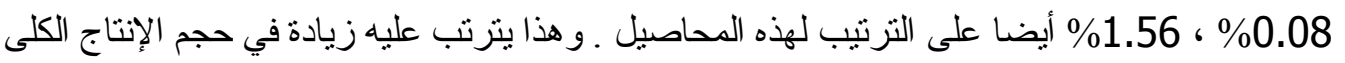

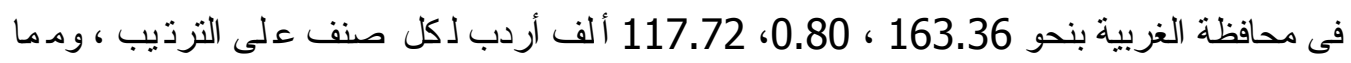

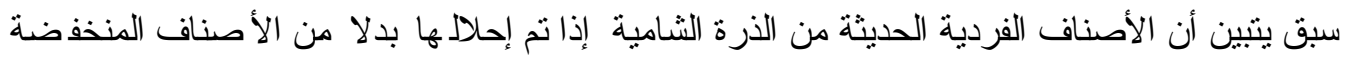

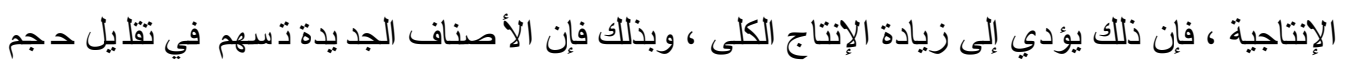

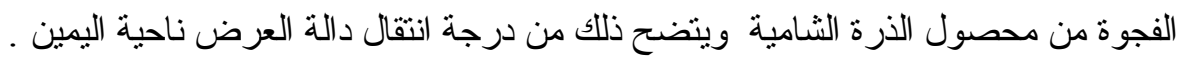

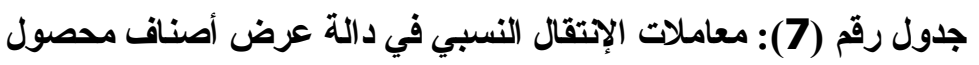

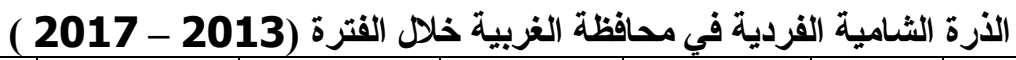

\begin{tabular}{|c|c|c|c|c|c|c|c|}
\hline فالإتثال النسبي & 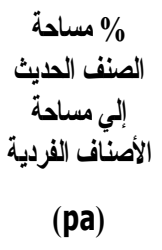 & معلف الصنتراج (1) & $\begin{array}{c}\text { إنتاجية الصنف } \\
\text { (لحديث } \\
\text { (ya) }\end{array}$ & 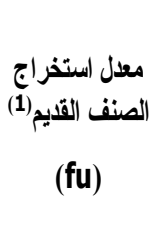 & $\begin{array}{l}\text { التنقية } \\
\text { القينة } \\
\text { (yu) }\end{array}$ & الصنف & p \\
\hline 1.58 & 10.42 & 0.93 & 26.2 & 0.94 & 22 & هـ 2030 & 1 \\
\hline 3.37 & 27.07 & 0.93 & 25.4 & 0.94 & 22 & هد 10 & 2 \\
\hline 0.11 & 1.26 & 0.93 & 24.4 & 0.94 & 22 & هـ 130 & 3 \\
\hline 0.03 & 10.53 & 0.93 & 22.3 & 0.94 & 22 & هـ 128 & 4 \\
\hline
\end{tabular}

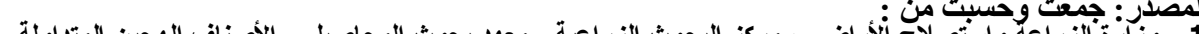

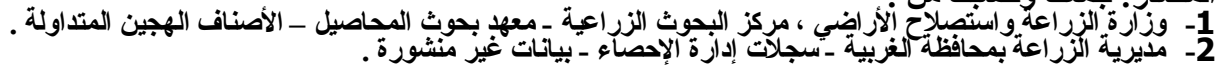


جدول رقم (8): الزيادة في الإنتاج للأصناف التي تم إحلالها من محصول

الأرة الثامية الفردية في خلا الفادئل الفترة (2013 - 2017)

\begin{tabular}{|c|c|c|c|c|c|c|c|}
\hline بالألف أردبادة & أردب الإتتاجية & المزروعة المساحة من & ف الإتيقال & 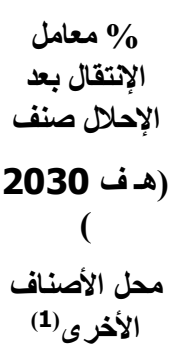 & الإتبال & الأصناف & p \\
\hline 163.36 & 25.4 & 8.81 & 0.73 & 4.10 & 3.37 & هـ ف 10 & 1 \\
\hline 0.80 & 24.4 & 0.41 & 0.08 & 0.19 & 0.11 & هـ ف 130 & 2 \\
\hline 117.72 & 22.0 & 3.43 & 1.56 & 1.59 & 0.03 & هـ ف 128 & 3 \\
\hline
\end{tabular}

(1) قررت من معادلة (هاري اير - و إدوارد شو) بعد إحلا إنتاجية صنف هـ. ت 2030 دهل إنتاجية الأصناف هـ.ف

10 ، هـف 130 ، هـ.ف 128

(2) عبارة عن متوسط المساحة× متوسط الإتتاجية × نسبة الفرق فى معامل الاتقال

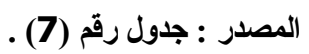

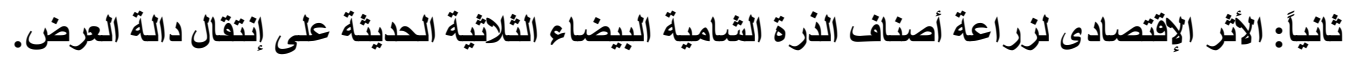
يتبين من الجدول رقم ( 9) أنه بزر اعة الأصناف الثثلثية الحديثة لمحصول الذرة الثنامية فإن النان

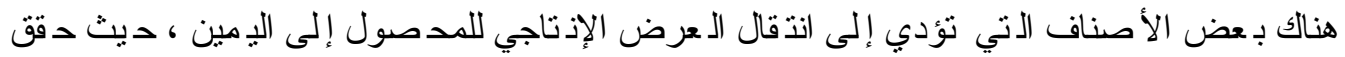

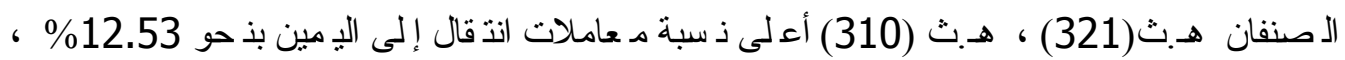

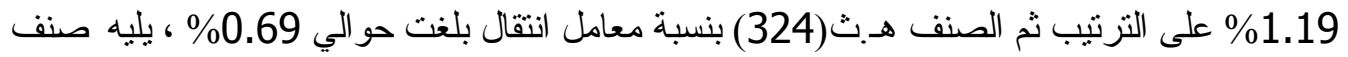

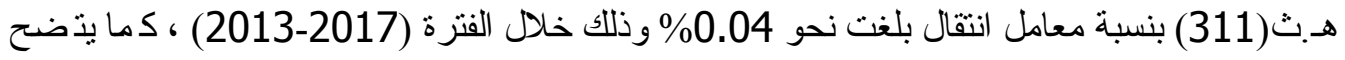

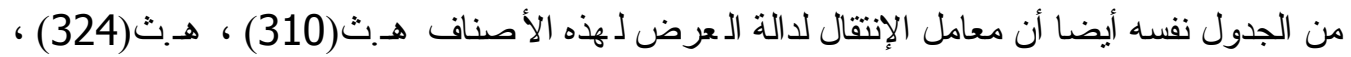

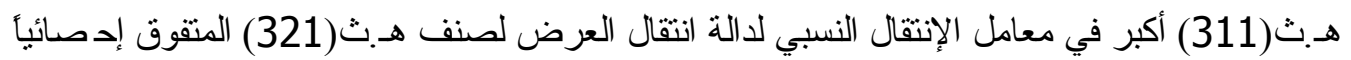
على هذه الأصناف ــ بإحلال الصنف هـ.ث(321) عالي الإنتاجية دهل كل من الأصناف الثناثة

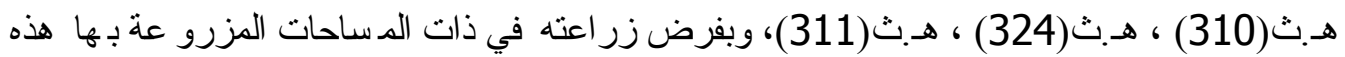

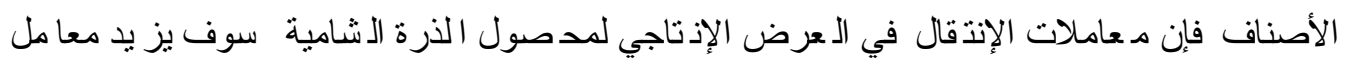

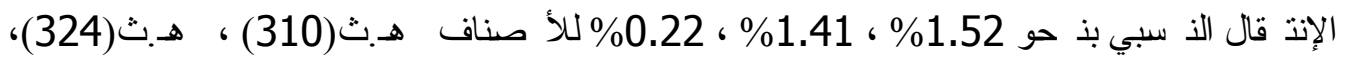

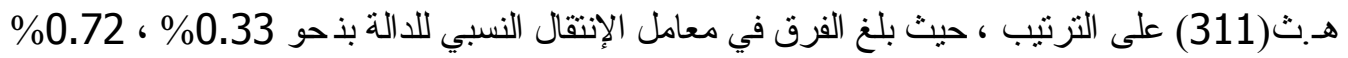

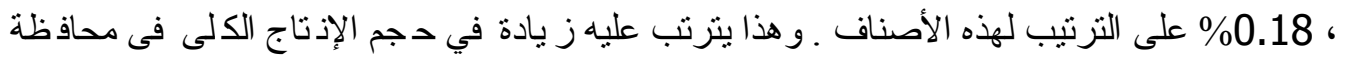

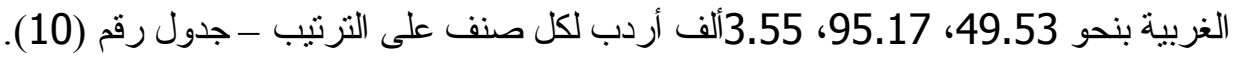

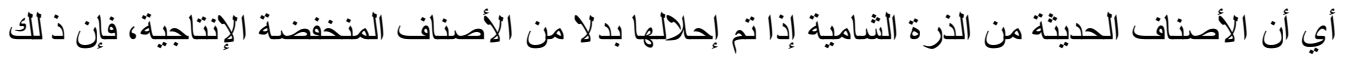

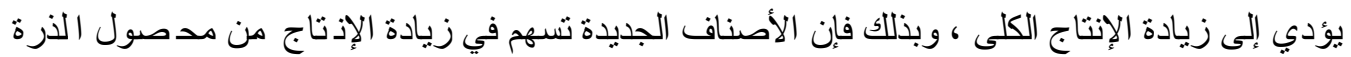

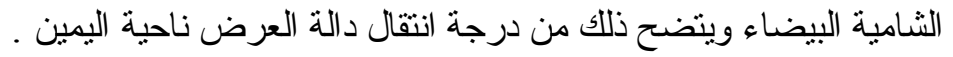


جدول رقم (9): معاملات الإنتقال النسبي في دالة عرض أصناف

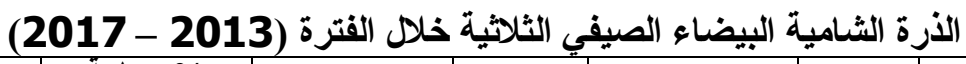

\begin{tabular}{|c|c|c|c|c|c|c|c|}
\hline النسبي في الإتبالة & 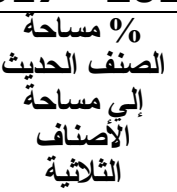 & معدل استفراج & ألصنتفية & معل الصنفر القيم(1) & القتاجفية & الصنف & م \\
\hline 12.53 & 77.51 & 0.93 & 24.6 & 0.94 & 20.4 & $\begin{array}{l}321 \\
321\end{array}$ & 1 \\
\hline 1.19 & 9.43 & 0.93 & 23.6 & 0.94 & 20.4 & $\begin{array}{l}\dot{3} \text { هـ } \\
310\end{array}$ & 2 \\
\hline 0.69 & 8.75 & 0.93 & 22.4 & 0.94 & 20.4 & $\begin{array}{l}\text { ثـ } 324 \\
324\end{array}$ & 3 \\
\hline 0.04 & 1.38 & 0.93 & 21.2 & 0.94 & 20.4 & $\begin{array}{l}\dot{\hat{H}} \\
311\end{array}$ & 4 \\
\hline
\end{tabular}

المصدر: جمعت وحسبت من :

1- وزارة الزراعة واستصلاح الأراضي ، مركز البحوث الزراعية ـ معهل بحوث المحاصيل ـ الأصناف الهجين المتداولة.

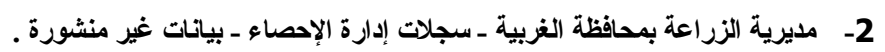

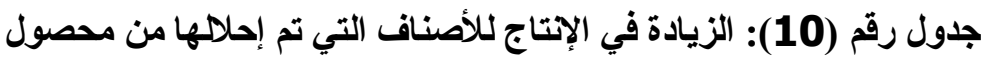

الأرة الثامية البيضاء الصيفى الثلاثية خلال الفترة (2013 (2017)

\begin{tabular}{|c|c|c|c|c|c|c|c|}
\hline ألزالألتاجة في & أردب / الإتاجِّة & الصنفروعة المّاحة من & \% مالفرق في & 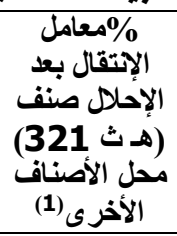 & الإِتَقال & الأصناف & p \\
\hline 49.53 & 23.6 & 6.36 & 0.33 & 1.52 & 1.19 & $\begin{array}{l}310 \\
310\end{array}$ & 1 \\
\hline 95.17 & 22.4 & 5.90 & 0.72 & 1.41 & 0.69 & $\begin{array}{l}324 \\
324\end{array}$ & 2 \\
\hline 3.55 & 21.2 & 0.93 & 0.18 & 0.22 & 0.04 & 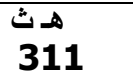 & 3 \\
\hline
\end{tabular}

(1) قُرت من معادلة (هاري اير -و إدوارد شو) بعد إحلا إنتاجية صنف ه ث 321 محل إنتاجية الأصناف ه ث 310 ، ه ث 324 ،

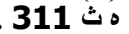
(2) عبارة عن منوسط المساحة × متوسط الإتاجية × نسبة الفرق فى معامل الاتقال

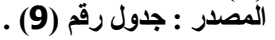

الخريطة الصنفية المقترحة لأصناف الذرة الثامية البيضاء بمحافظة الغربية .

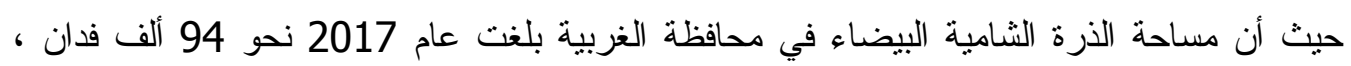

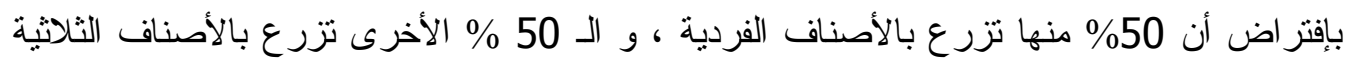

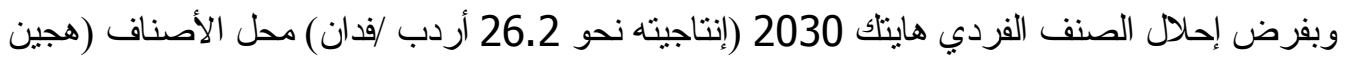

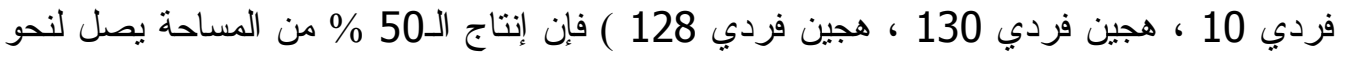

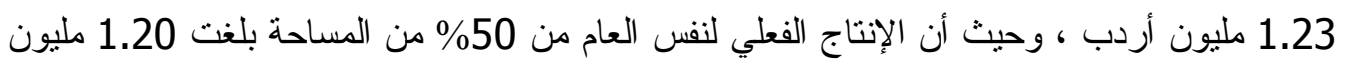

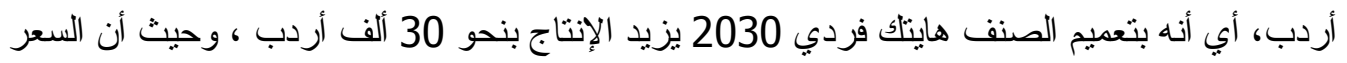

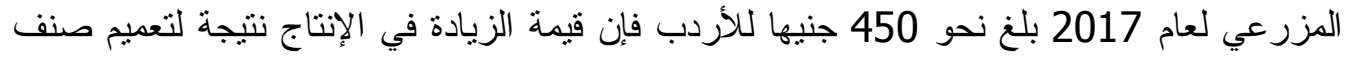

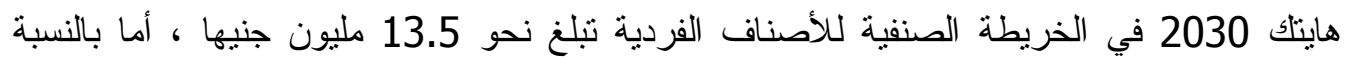
للأصناف الثلاثية فبإفتر اض أنها تزر ع على 50\% من مسكاحة الذرة الثامية لموسم 2017 ، و وبإحلال

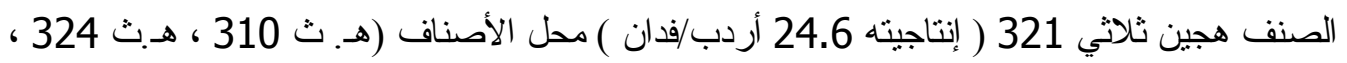

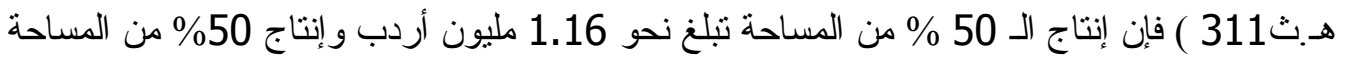

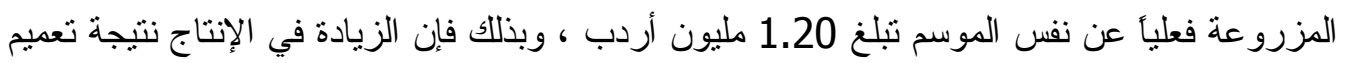


صنف ثناثي 321 تبلغ نحو 40 ألف أردب ثبلغ قيمتها بالسعر المزرعي 450 جنيه /أردب نبلغ نحو 18 مليون جنيه ، وبذلك فإن إجمالي قيمة الزيادة عن انتقال دالة العرض للأصناف الفردية و الثناثية

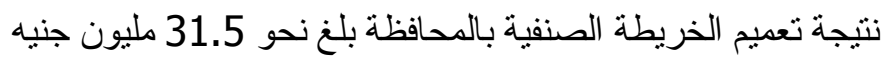
ـ دوال انتاج محصول الذرة الثامية البيضاء

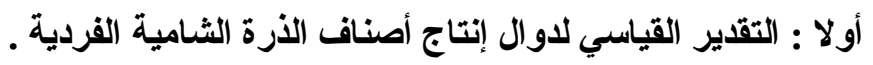
1 - :

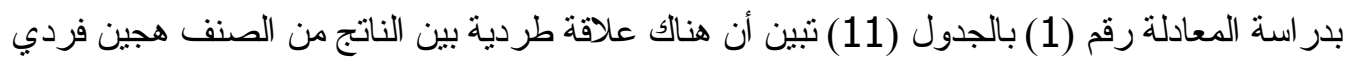

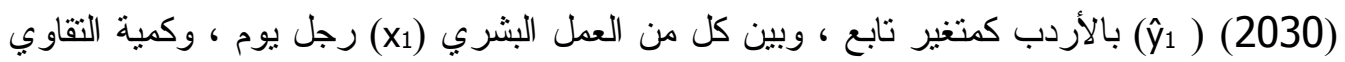

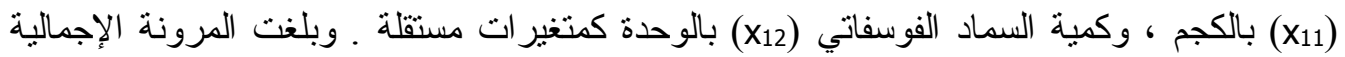

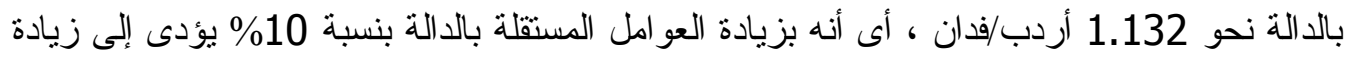
الناتج الرئيسي من هذا الصنف بنسبة 11.32\% و هى علاقة العائد المتز ايد للسعة ، أب أن الإنتاج يتم في المرحلة الأولي ـ وبتقدير التوزيع الوظيفي للعوامل المفسرة للدالة: نبين أن نصيب كل من من العمل

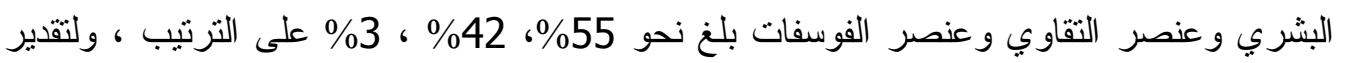

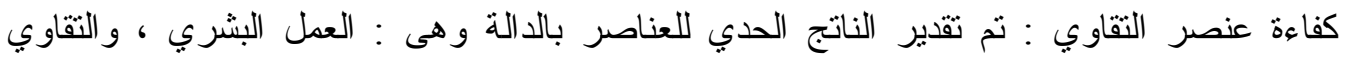

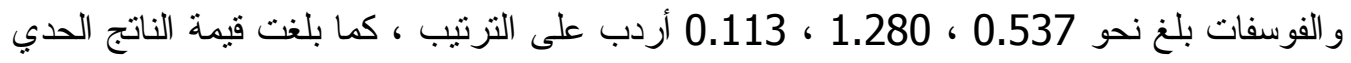

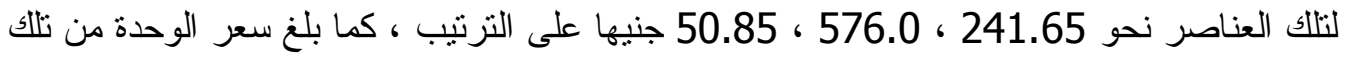
العناصر نحو 48.32 ، 58.06 ، 7 جنيه لتللك العناصر على الترتيب - جدول رقم (4) (4) بالملحق ،

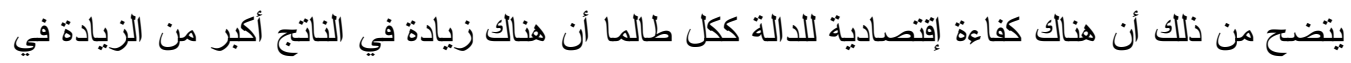

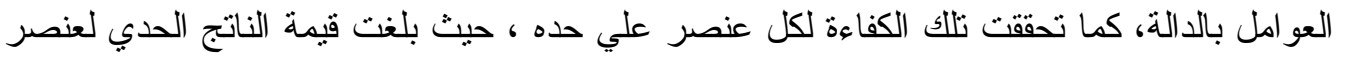

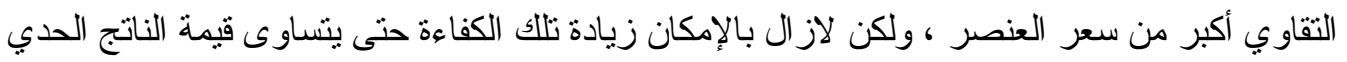
لعنصر التقاوي مع سعره في السوق ، أي أن عنصر النقاوي قد حقق كفاءة اقتصادية ويؤثر في الناتج

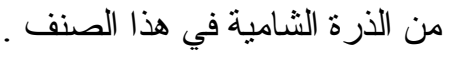

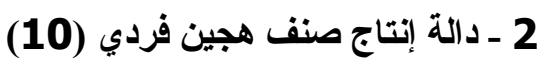

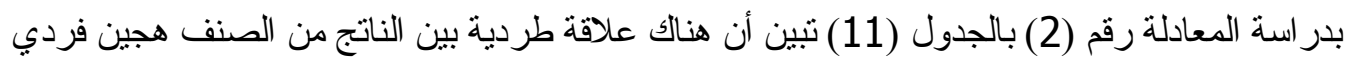

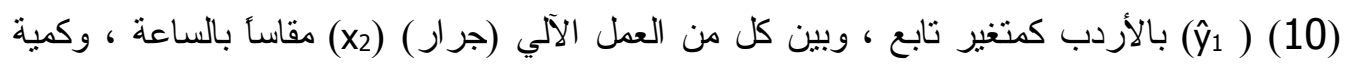

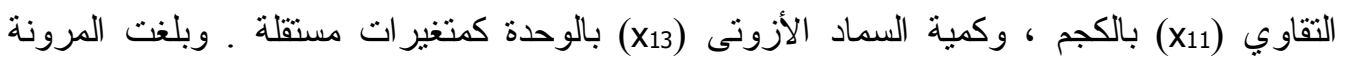

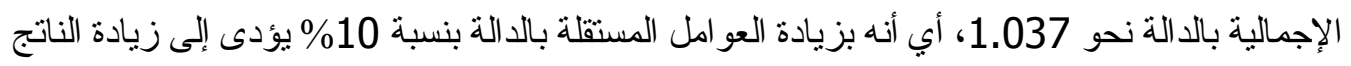
الرئيسي من هذا الصنف بنسبة 10.37\% وهى علافة إنتاجية متز ايدة ، وبتقدير التوزيع الوظيفي بالئي

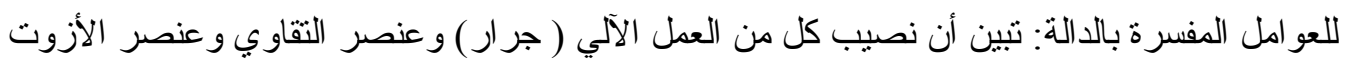

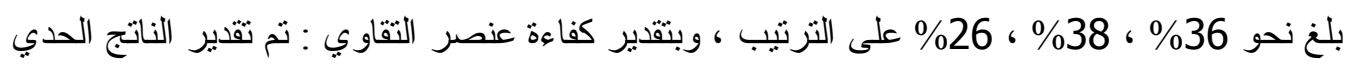

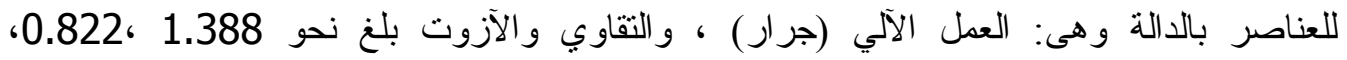

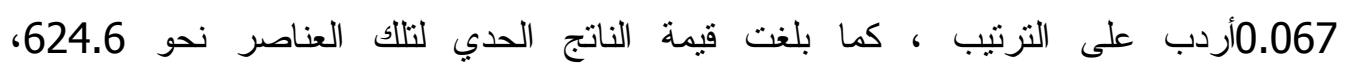

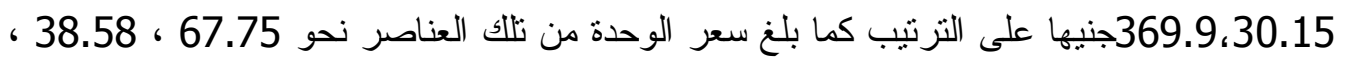
7.38 جنيها لتلك العناصر على الترتيب - جدول رقم (4) بالملحق ، ويتضح من ذلك أن هناك كفاءة 
جدول رقم (11 ) : دوال الإتتاج لمحصول الذرة الثامية البيضاء وفقاً للأصناف

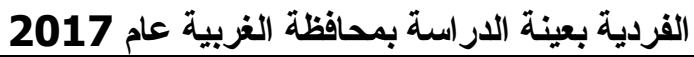

\begin{tabular}{|c|c|c|c|c|c|c|}
\hline المعنوية & $\begin{array}{c}\text { F } \\
\text { المحسوبة }\end{array}$ & $\mathbf{R}^{2}$ & المرونة & المعادلة المقدرة & الصنف & المعادئة \\
\hline$* *$ & 189.34 & 0.972 & 1.132 & $\begin{array}{cc}\mathbf{L y}_{\mathbf{1 i}}=\mathbf{- 0 . 1 5 8}+\mathbf{0 . 6 5 9} \mathbf{L X}_{\mathbf{1}}+ \\
\mathbf{0 . 5 0 6} \mathbf{L X}_{\mathbf{1 1}}-\mathbf{0 . 0 3 3} \mathbf{L X}_{\mathbf{1 2}} \\
\quad(4.930)^{* *}( \\
6.586)^{* *} & (-2.479)^{*}\end{array}$ & (2030) فردين & 1 \\
\hline$* *$ & 99.801 & 0.952 & 1.037 & $\begin{array}{c}L_{y_{2 i}}=0.293+0.374 L_{X_{2}}+ \\
0.394 \mathbf{L X}_{11}+0.269 \mathrm{LX}_{13} \\
(4.724)^{* *} \\
(3.029)^{*}(3.815)^{* *}\end{array}$ & فردين & 2 \\
\hline$* *$ & 499.25 & 0.985 & 1.055 & 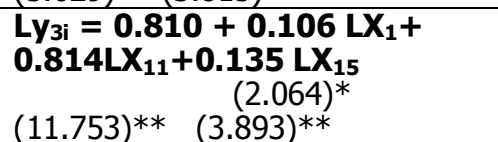 & $\begin{array}{c}\text { فردين } \\
\text { فجين (130) }\end{array}$ & 3 \\
\hline$* *$ & 156.69 & 0.964 & 1.381 & 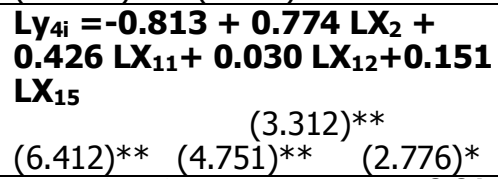 & $\begin{array}{c}\text { فزينين } \\
\text { فزين (128) }\end{array}$ & 4 \\
\hline
\end{tabular}

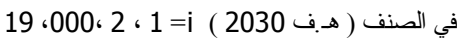

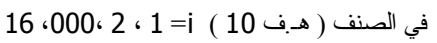

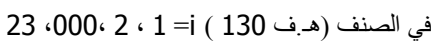

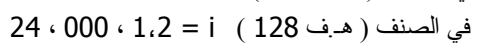

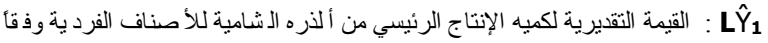

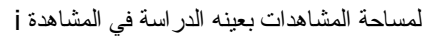

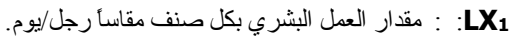
LX2

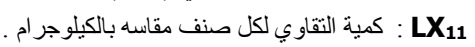
LX L LX

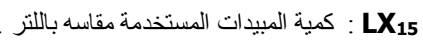

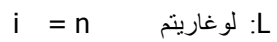

المصدر : حسبت من إستمار ات إستبيان العينة

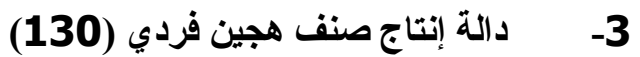

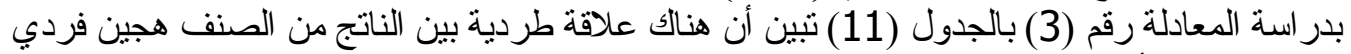

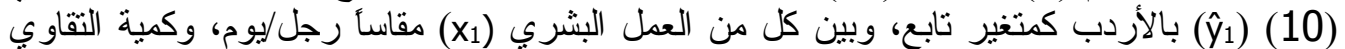

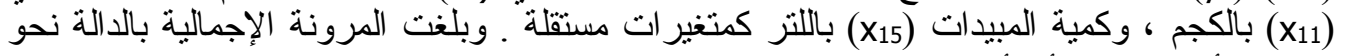

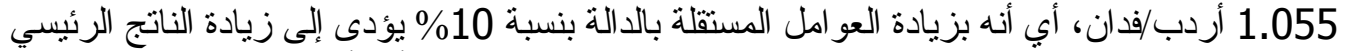

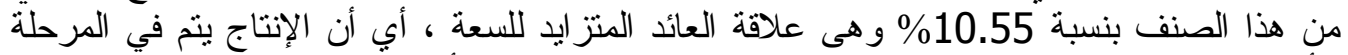

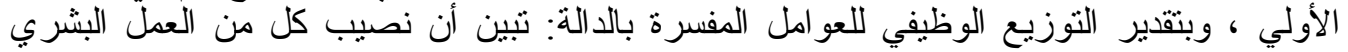

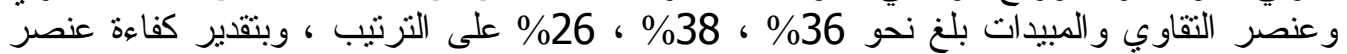

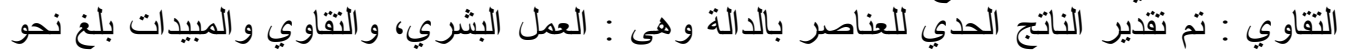

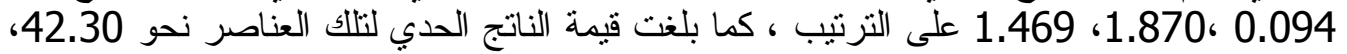

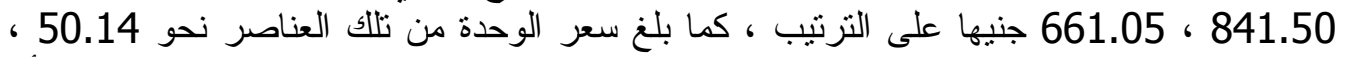

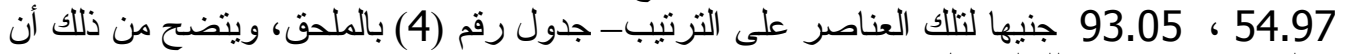
هنالك كفاءة إقتصادية للدالة ككل هن

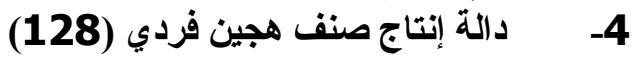

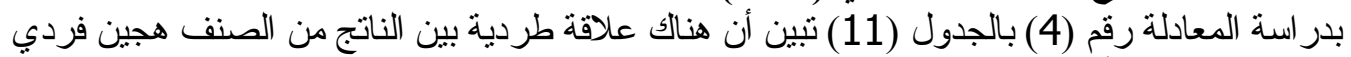

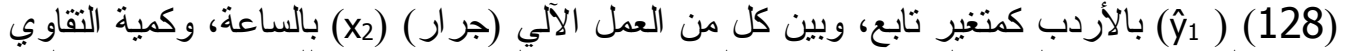

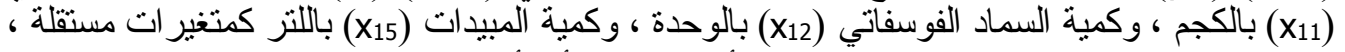

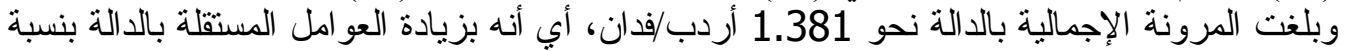

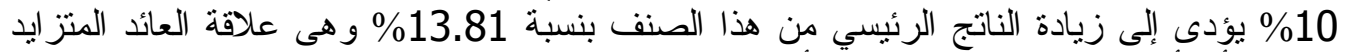

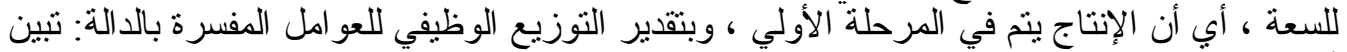

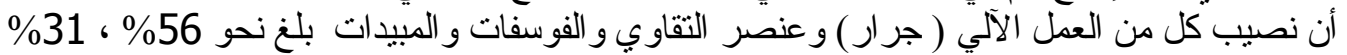




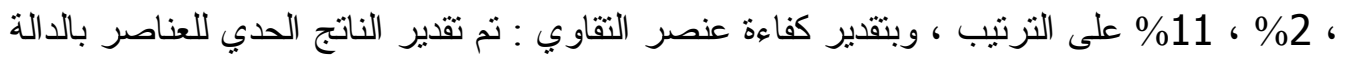
و هى : العمل الآلي (جر ار) ، و التقاو وي و الفوسفات و المبيدات بلغ نحو

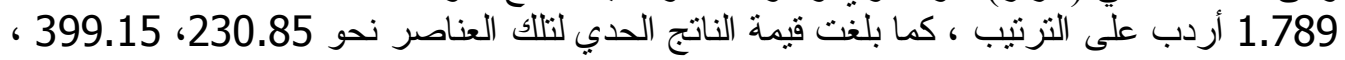

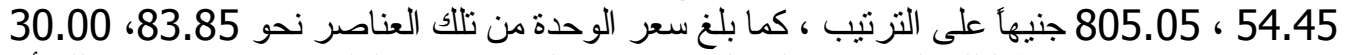

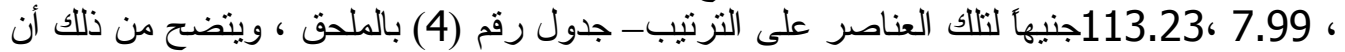

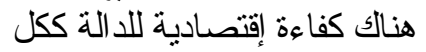

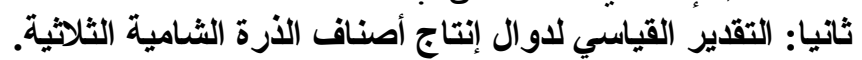
1 -

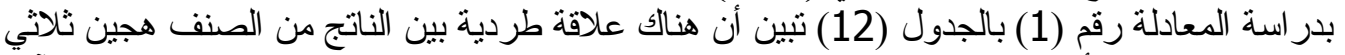

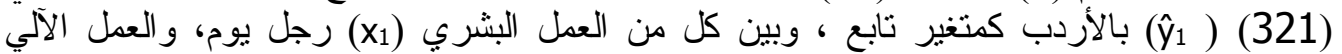

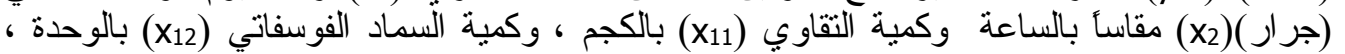

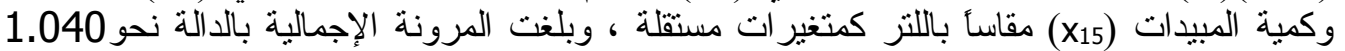

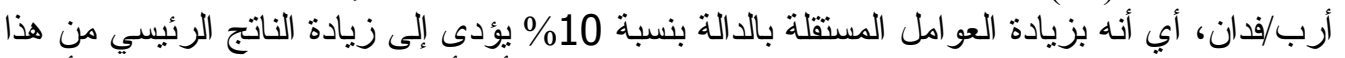

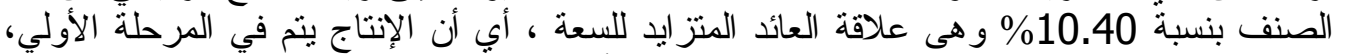

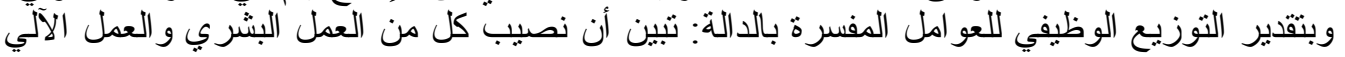

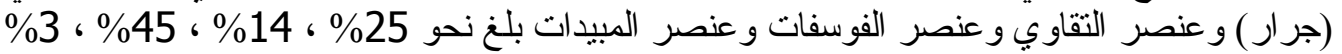

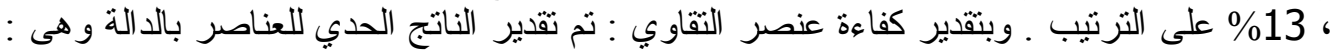

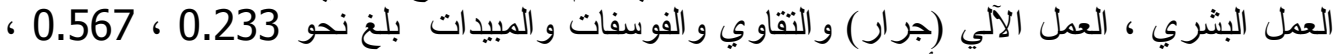

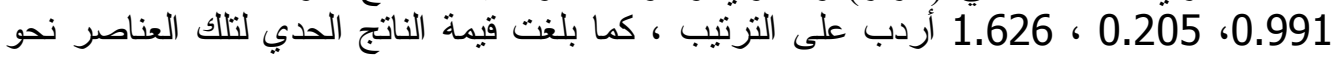

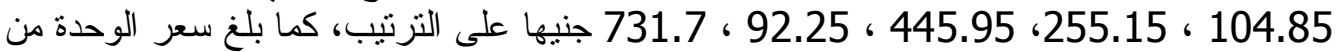

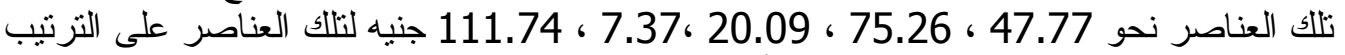
- جدول رقم (5) بالملحق ، يتضح من ذللك أن هناك كفاءة إقتصادية للد اللة ككل.

2-2

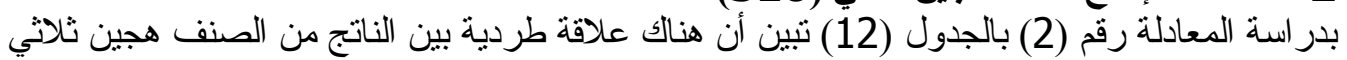

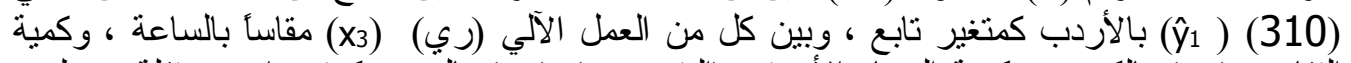

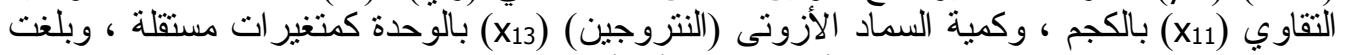

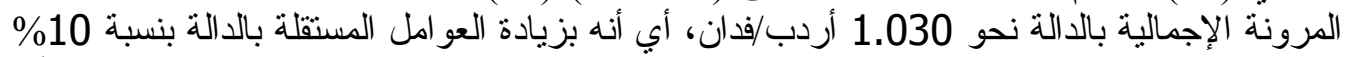

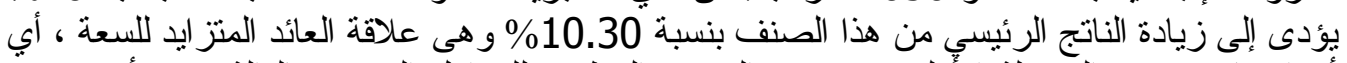

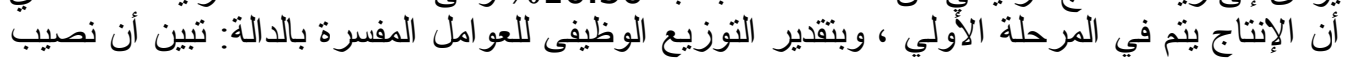

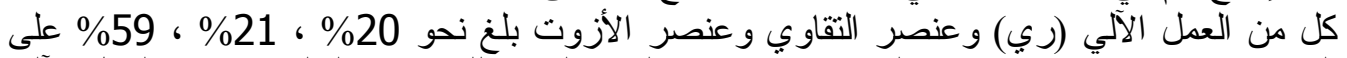

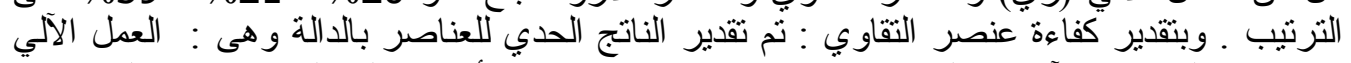

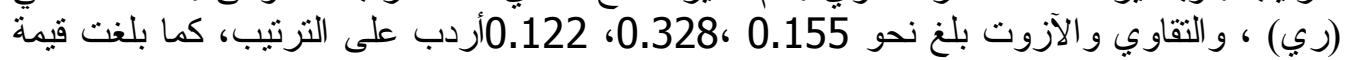
الناتج الحدي لنالك العناصر نحو 22.48، 69.75، 147.6،

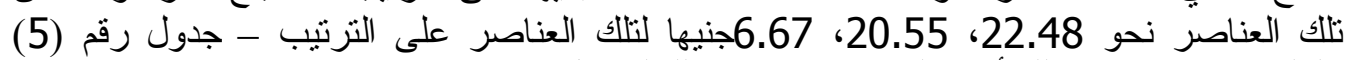
بالملحق، ويتضح من ذلك أن هنالك كفاءة إقتصادية للالد الة ككل

3- دالة إنتاج صنف هجين ثلاثي (324)

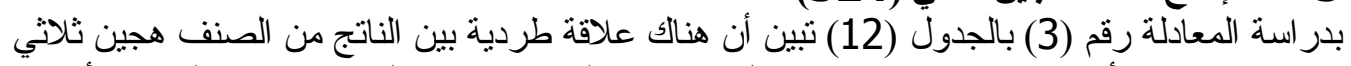

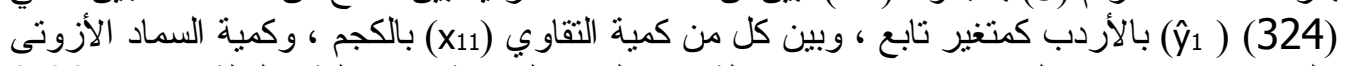

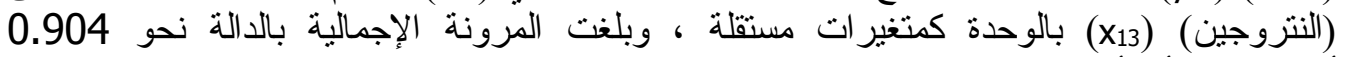

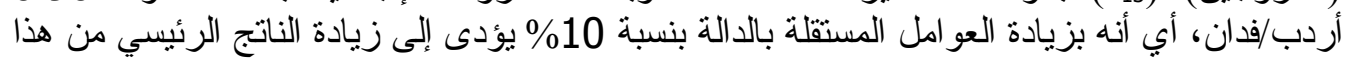

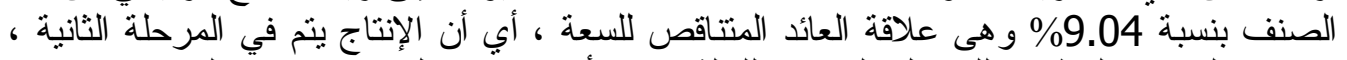

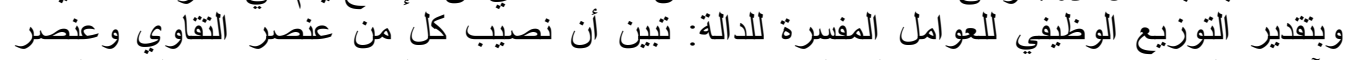

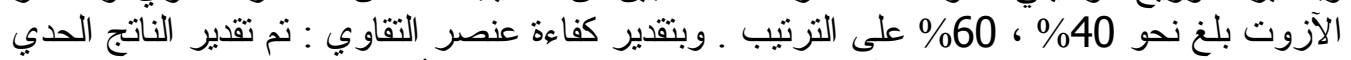

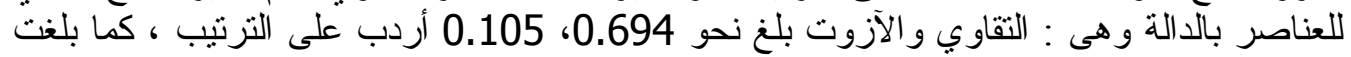
قيمة الناتج الحدي لتلكى العناصر نحو

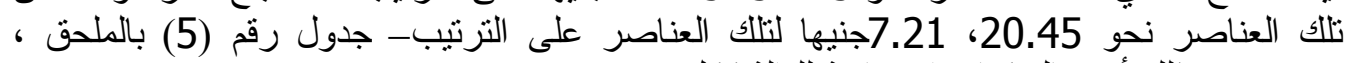
ويتضح من ذلك أن هناك كفاءة إقتصادية للدالة ككل. 
جدول رقم (12 ) : دوال الإتتاج لمحصول الذرة الثامية البيضاء وفقاً للأصناف الثلاثية بعينة الدر اسة بمحافظة الغربية عام 2017

\begin{tabular}{|c|c|c|c|c|c|c|}
\hline المعنوية & المحسوية F & $\mathbf{R}^{2}$ & المرونة & المعادلة المقلرة & الصنف & المعادئة \\
\hline$* *$ & 260.15 & 0.942 & 1.040 & 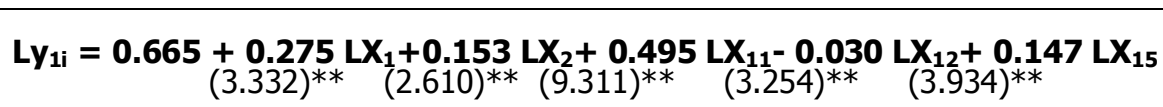 & هـ .ث (321) & 1 \\
\hline$* *$ & 272.54 & 0.976 & 1.030 & 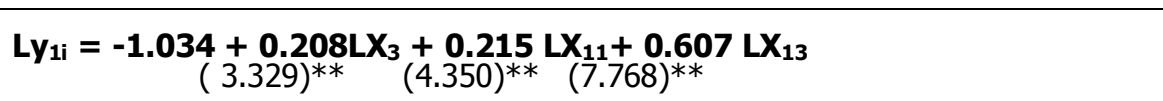 & هـ .ث (310) & 2 \\
\hline$* *$ & 124.84 & 0.932 & 0.904 & 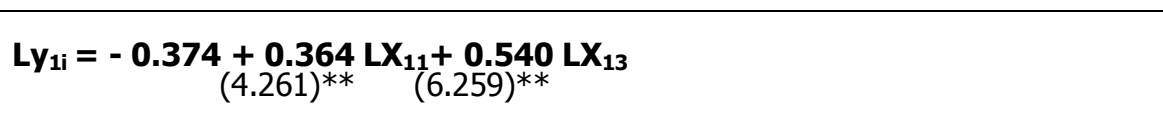 & هـ .ثે(324) & 3 \\
\hline$* *$ & 121.26 & 0.923 & 1.094 & 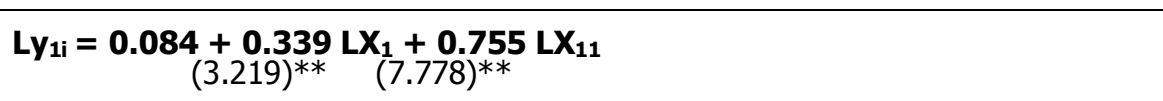 & هـ .ثે(311) & 4 \\
\hline & & & & 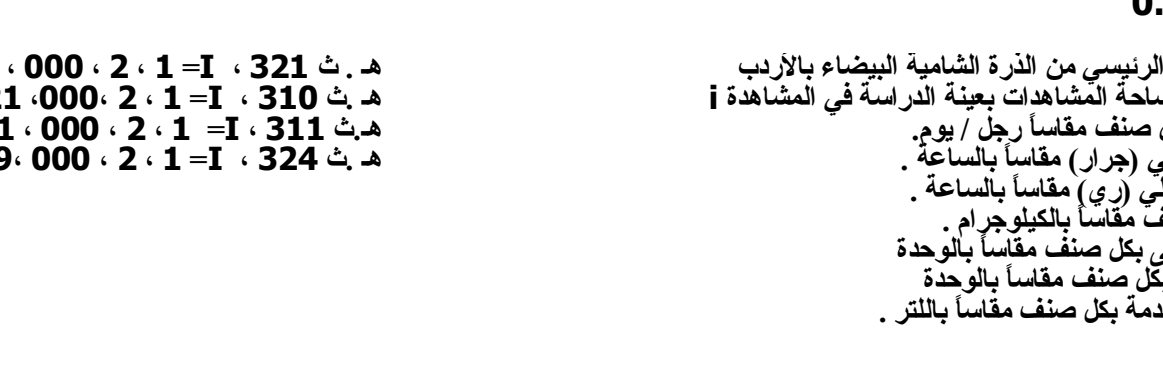 & 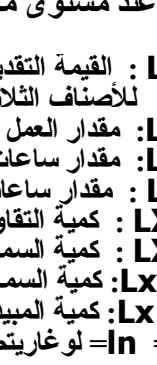 & \\
\hline
\end{tabular}


4- دالة إنتاج صنف هجين ثلاثي (311) بدر اسة المعادلة رقم (4) بالجدول (12) تبين أن هنالك علاقة طردية بين الناتج من الصنف هجين ثلاثي

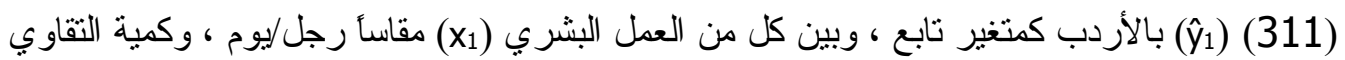

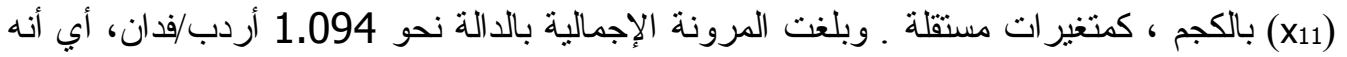

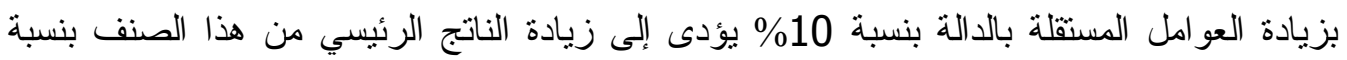

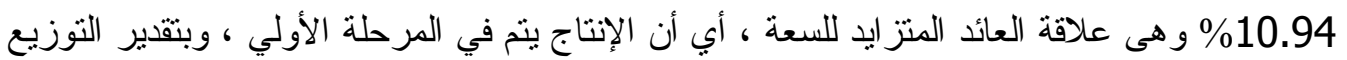

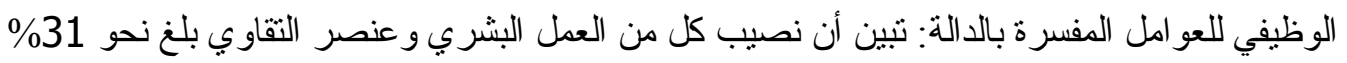

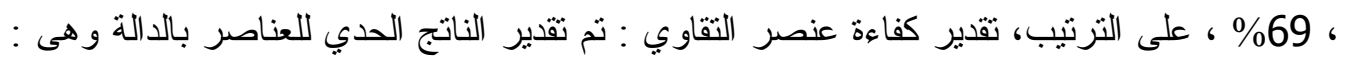

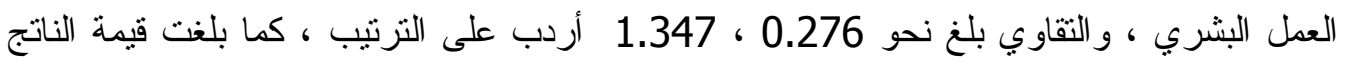
الحدي لتلك العناصر نحو 124.2، 606.15 جنيها على الترتيب ، كما بلغ سعر الوحدة من تلكي العناصر نحو 48.26، 19.24جنيها لتلك العناصر على التزتيب- جدول رقم (5) بالملحق ، ويتضح

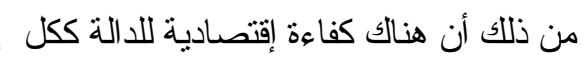

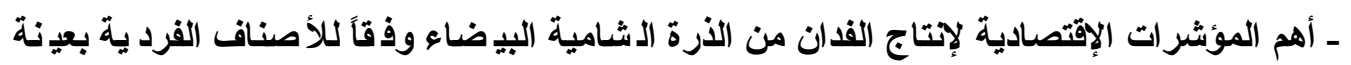
الار اسة بمحافظة الغربية بدراسة البيانات الواردة بالجدول رقم (13) تبين أن متوسط إنتاجية الفدان من أصناف الذرة الثامية

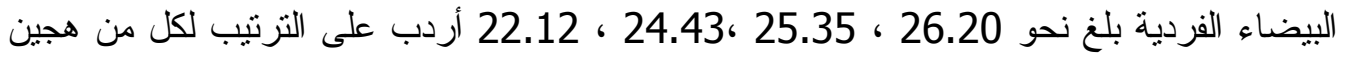
فردي (2030) ، هجين فردي (10) ، هجين فردي (130) ، هجين فردي (128) ، وذلك في عام 2017

كما بلغ إجمالي العائد للفدان لتلك الأصناف نحو 12415 ، 1241 ، 11841 ، 11448 ، 114 ، 10509 جنيها لتلكي

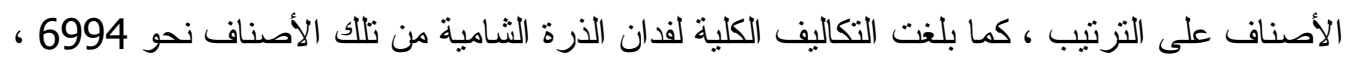

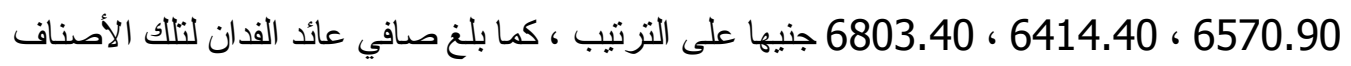

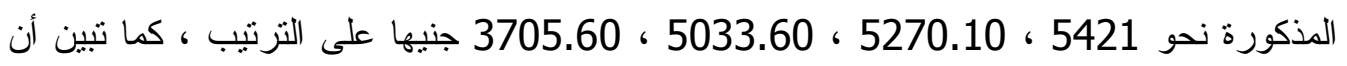

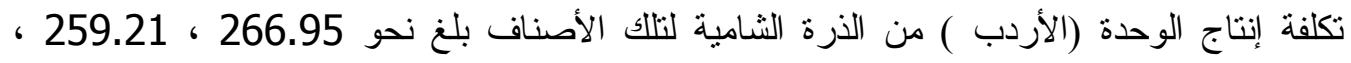

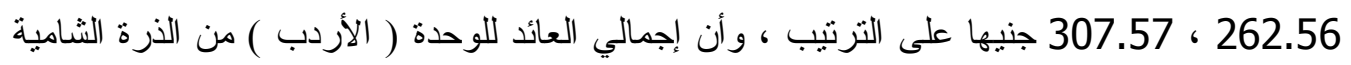

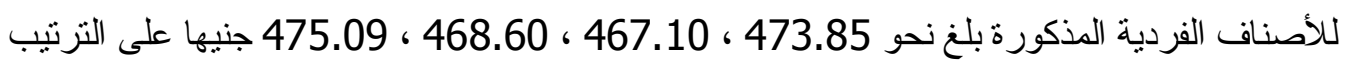

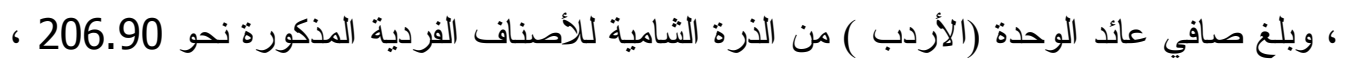

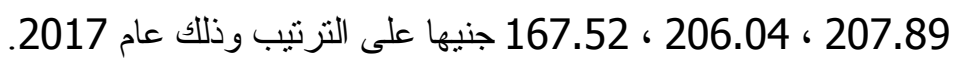

وتم إستنتاج بعض المقاييس الإقتصادية ومن أهمها :

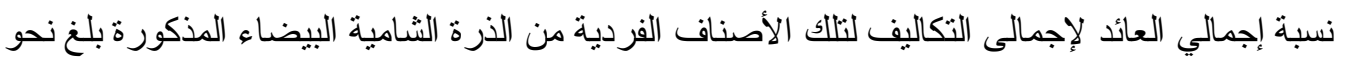

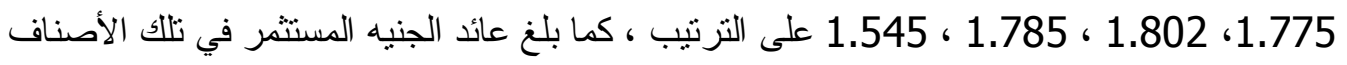

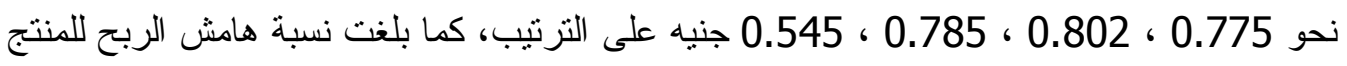

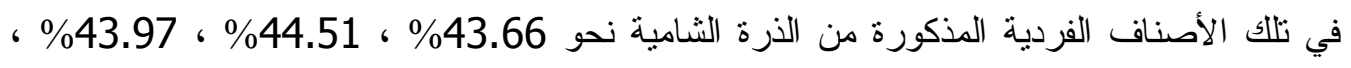

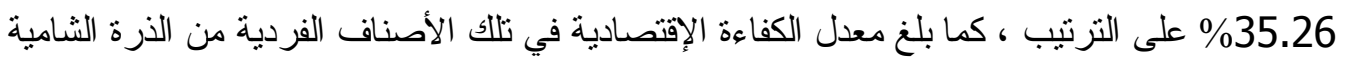

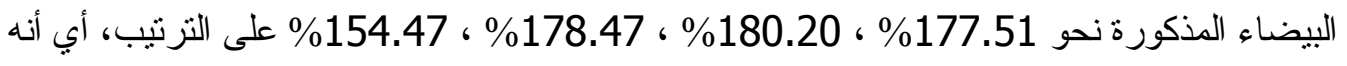

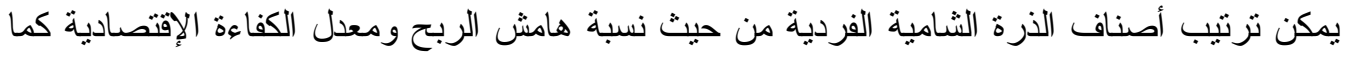

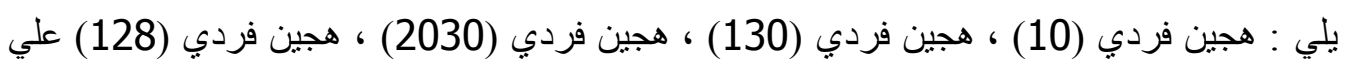
الترنيب وذلك عام 2017 : هين فردي 
ـ أهم المؤشر ات الإقتصادية لإنتاج الفدان من الذرة الشامية البي ضاء وفّا للأصناف الثلاذية بعينة

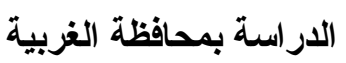
بدر اسة البيانات الواردة بالجدول رقم ( 16) تبين أن متوسط إنتاجية الفدان من أصناف الذرة الثامية

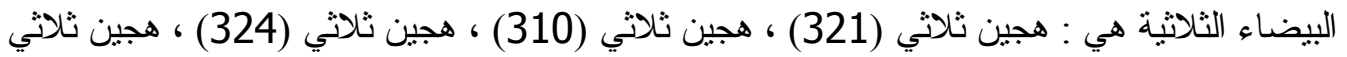

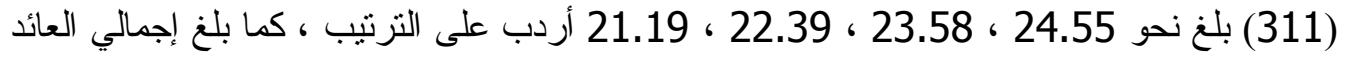

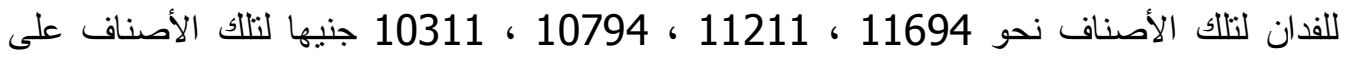
الترنيب ، كما بلغت التكاليف الكلية لفدان الذرة الثامية من تلك الأصناف نحو 6758.80 ، 67030 8709.20 ، 6633.40 ، 6329.80 جنيها على التزتيب ، كما بلغ صافي عائد الفدان لتلك التك

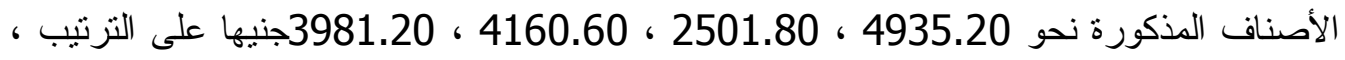

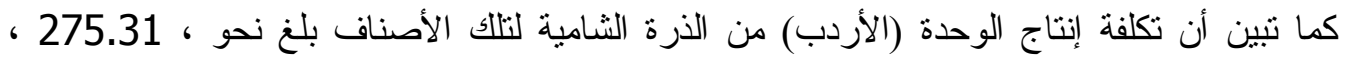

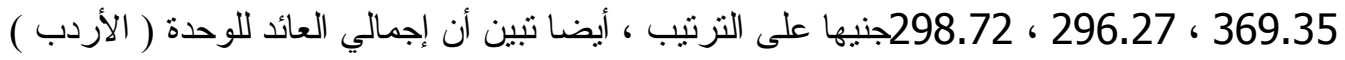
من الذرة الثنامية للأصناف الثناثية المذكورة بلغ نحو 476.33 ، 475.45 ، 4752.09 جنيها على الترتيب ، كما تبين أن صافي عائد الوحدة (الأردب) من الذرة الثامية للأصناف الثناثية ،

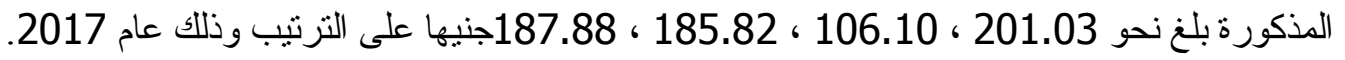
جدول رقم ( 13): أهم المؤشرات الإقتصادية لإتتاج الفدان من الذرة الثامية وفقا للأصناف الفردية

و الثثلاثية بعينة الدراسة بمحافظة الغربية عام 2017

\begin{tabular}{|c|c|c|c|c|c|c|c|c|c|}
\hline \multicolumn{4}{|c|}{ الأصناف الثلاذية } & \multicolumn{4}{|c|}{ الأصناف الفردية } & \multirow[t]{2}{*}{ اليبان } & \multirow[b]{2}{*}{ p } \\
\hline $\begin{array}{c}3 . A \\
(311)\end{array}$ & $\begin{array}{c}3.4 \\
(324)\end{array}$ & $\begin{array}{c}3 . \Delta \\
(310)\end{array}$ & $\begin{array}{c}3.4 \\
(321)\end{array}$ & $\begin{array}{c}\text { هـ. } \\
(\mathbf{1 2 8})\end{array}$ & $\begin{array}{c}.4 \\
(\mathbf{1 3 0})\end{array}$ & $\begin{array}{l}\text { (10) } \\
\text { (10) }\end{array}$ & $\begin{array}{c}\text { ه. } \\
(2030)\end{array}$ & & \\
\hline 21.19 & 22.39 & 23.58 & 24.55 & 22.12 & 24.43 & 25.35 & 26.20 & إنتاجيةُ الفأن (بالأردب) & 1 \\
\hline 10311.00 & 10794.00 & 11211.00 & 11694.0 & 10509.0 & 11448.0 & 11841.0 & 12415.0 & إجمالّي العائد للفّان (بالجنبه ) & 2 \\
\hline 4079.80 & 4312.90 & 6168.10 & 4371.90 & 4573.40 & 4032.70 & 4285.80 & 4809.80 & 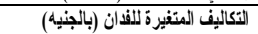 & 3 \\
\hline 2250.0 & 2320.50 & 2541.10 & 2386.90 & 2230.0 & 2381.70 & 2285.10 & 2184.20 & 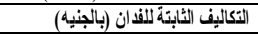 & 4 \\
\hline 6329.80 & 6633.40 & 8709.20 & 6758.80 & 6803.40 & 6414.40 & 6570.90 & 6994.0 & التكاليف الكلية للفان (بالجنية)(1) & 5 \\
\hline 3981.20 & 4160.60 & 2501.80 & 4935.20 & 3705.60 & 5033.60 & 5270.10 & 5421.0 & صافي عائد الفذان (بالجنيه)(2) & 6 \\
\hline 298.72 & 296.27 & 369.35 & 275.31 & 307.57 & 262.56 & 259.21 & 266.95 & تكلفة إنتاج الوحدة (أردب) (بالجنية) (3) & 7 \\
\hline 486.60 & 482.09 & 475.45 & 476.33 & 475.09 & 468.60 & 467.10 & 473.85 & إجمالي العائد للأزادب (بالجنبه)(4) & 8 \\
\hline 187.88 & 185.82 & 106.10 & 201.03 & 167.52 & 206.04 & 207.89 & 206.90 & صافي عائد الأرلب (بالجنية) & 9 \\
\hline 1.629 & 1.627 & 1.287 & 1.730 & 1.545 & 1.785 & 1.802 & 1.775 & إجمالي العائد لإجمالي التكاليف(5) & 10 \\
\hline 0.629 & 0.627 & 0.287 & 0.730 & 0.545 & 0.785 & 0.802 & 0.775 & عائد الجنجيه المستئُّم (6) & 11 \\
\hline$\% 38.61$ & $\% 38.55$ & $\% 22.32$ & $\% 42.20$ & $\% 35.26$ & $\% 43.97$ & $\% 44.51$ & $\% 43.66$ & نسبة هامش الربح \% (7) & 12 \\
\hline$\% 162.90$ & $\% 162.72$ & 128.73 & $\% 173.02$ & $\% 154.47$ & $\% 178.47$ & $\% 180.20$ & $\% 177.51$ & مدلال الكفاءة الإقتصالية \% (8) & 13 \\
\hline
\end{tabular}

المصدر : حسبت من إستمارات إستبيان العينة .

\section{وتم إستتناج بعض المقاييس الإقتصادية ومن أهمها :}

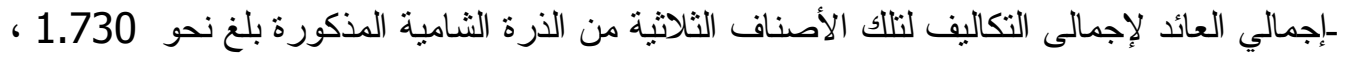

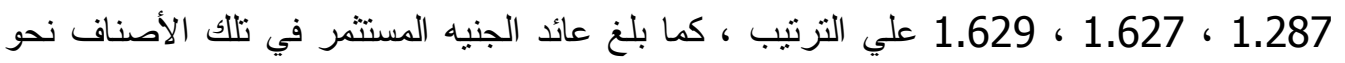

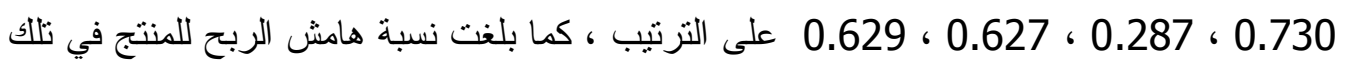

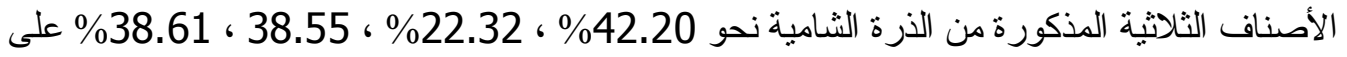

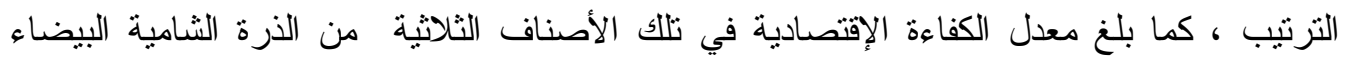

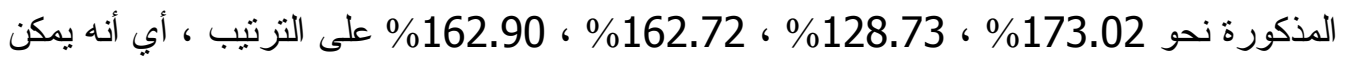
ترنيب أصناف الذرة الثامية الثلاثية من حيث نسبة هامش الربح ومعدل الكفاءة الإقتصادية كما يلي : هجين ثلاثي (321) ، هجين ثلاثي (311) ، هجين ثلاثي (324) ، هجين ثلاثي (310) علي الترتيب وذنلك عام 2017 . 


\section{الملاحق}

ملحق رقم (1) : أعداد الزراع و المساحة المزروعة لمحصول الذرة الثامية البيضاء الصيفية وفقا للأصناف بمراكز وقري العينة المختارة بمحافظة الغربية عام 2017.

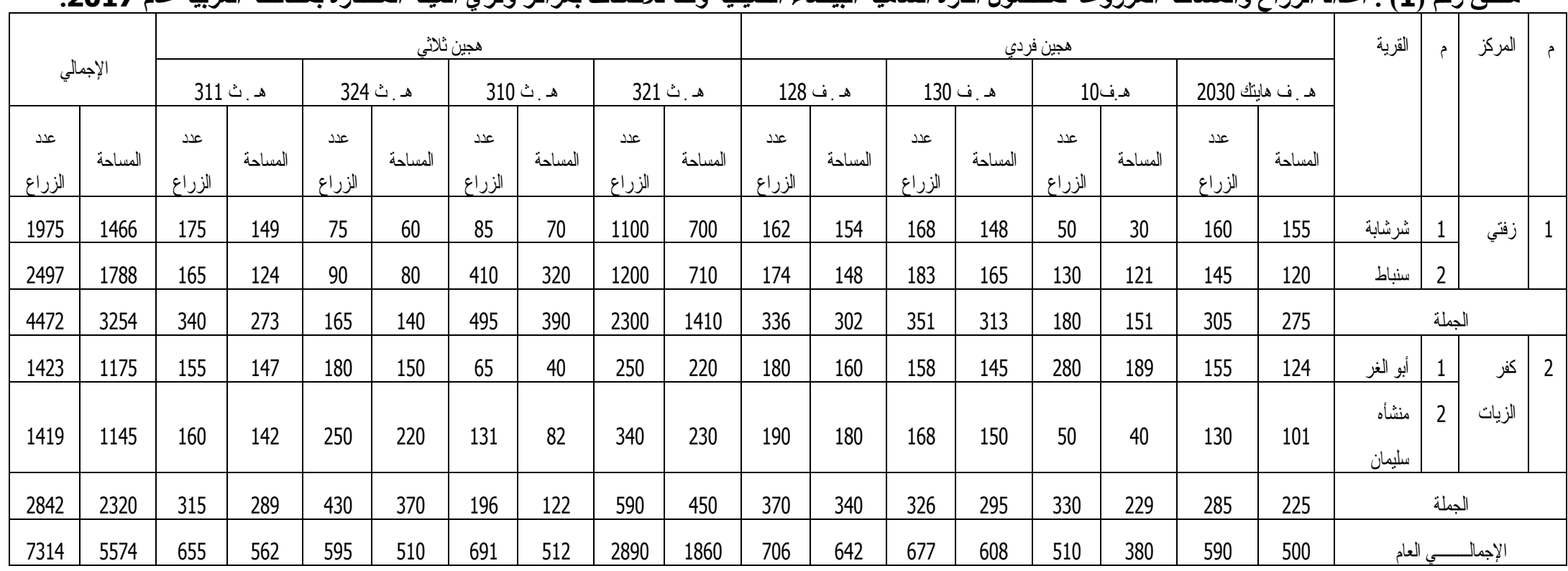

1 - مديريه الزراعة بالغربية ، سجلات إدارة الإحصاء ، بيانات غير منشوره

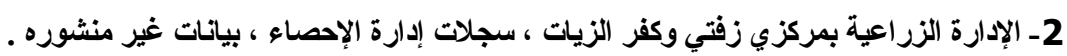


ملحق رقم (2) : تحديد عدد الحائرين المختارين من المزارع لمحصول الذرة الثنامية البيضاء الصيفية وفقاً للأصناف بعينة الدراسة بمحافظة الغربية عام 2017.

\begin{tabular}{|c|c|c|c|c|c|c|c|c|c|c|c|}
\hline كساينة & عدد الحائزين & الوسطي الهنسي & الوسط الهندسي & النسبة المئوية للمساحة في & للحائزين \% النسبة المئوية & $\begin{array}{c}\text { اللسبة المئوية } \\
\text { اللمساحة } \\
\text { \% }\end{array}$ & الحانزين & بالفدان & & الصنف & b \\
\hline $31 / 1$ & 19 & 8.53 & 8.51 & 72.39 & 8.07 & 8.97 & 590 & 500 & \multirow{4}{*}{ 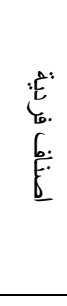 } & $\begin{array}{r}2030 \text { هـ . ف هايتك } \\
\end{array}$ & 1 \\
\hline $32 / 1$ & 16 & 6.91 & 6.89 & 47.54 & 6.97 & 6.82 & 510 & 380 & & هـفـ10 & 2 \\
\hline $29 / 1$ & 23 & 10.08 & 10.05 & 101.03 & 9.26 & 10.91 & 677 & 608 & & هـ . ف 130 & 3 \\
\hline $29 / 1$ & 24 & 10.57 & 10.54 & 111.17 & 9.65 & 11.52 & 706 & 642 & & هـ . ف 128 & 4 \\
\hline $35 / 1$ & 81 & 36.40 & 36.31 & 1318.45 & 39.51 & 33.37 & 2890 & 1860 & \multirow{4}{*}{ 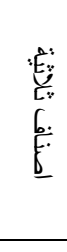 } & هـ بث & 5 \\
\hline $33 / 1$ & 21 & 9.34 & 9.32 & 86.85 & 9.45 & 9.19 & 691 & 512 & & هــث & 6 \\
\hline $31 / 1$ & 19 & 8.65 & 8.63 & 74.48 & 8.14 & 9.15 & 595 & 510 & & هـ . ث 324 & 7 \\
\hline \multirow[t]{2}{*}{$31 / 1$} & 21 & 9.52 & 9.50 & 90.32 & 8.96 & 10.08 & 655 & 562 & & هـ ثـ 311 & 8 \\
\hline & 224 & 100 & 99.75 & & 100 & 100 & 7314 & 5574 & \multicolumn{3}{|c|}{ الجملة } \\
\hline
\end{tabular}

المصدر : جمعت وحسبت من ملحق رقم (1) 
ملحق رقم (3) : توزيع عينه الدراسة من الزراع علي القري المختارة وفقا لأصناف الذرة الثنامية بححافظة الغربية عام 2017

\begin{tabular}{|c|c|c|c|c|c|c|c|c|c|c|c|c|c|c|c|c|c|c|c|c|}
\hline \multirow{3}{*}{ الجمالي } & \multicolumn{8}{|c|}{ هجين ثلاثي } & \multicolumn{8}{|c|}{ هجين فردي } & \multirow[b]{3}{*}{ القرية } & \multirow[b]{3}{*}{ s } & \multirow[b]{3}{*}{ المركز } & \\
\hline & \multicolumn{2}{|c|}{ هـ .ث 311} & \multicolumn{2}{|c|}{ هـ . ث 324} & \multicolumn{2}{|c|}{ هـ .ث 310} & \multicolumn{2}{|c|}{ هـ . ث 321} & \multicolumn{2}{|c|}{ هـ ـ ف 128} & \multicolumn{2}{|c|}{ هـ . ف 130} & \multicolumn{2}{|c|}{ هـــ10 } & \multicolumn{2}{|c|}{ هـ ـ ف هايتك 2030} & & & & \\
\hline & المثاهدات & الزراع & المشاهدات & الزراع & المشاهدات & الزراع & المشاهدات & الزراع & المشاهدات & الزراع & المشاهدات & الزراع & المشاهدات & الزراع & المشاهدات & الزراع & & & & ? \\
\hline 61 & 6 & 175 & 2 & 75 & 3 & 85 & 31 & 1100 & 6 & 162 & 6 & 168 & 2 & 50 & 5 & 160 & شرشابه & 1 & & \\
\hline 75 & 5 & 165 & 3 & 90 & 12 & 410 & 34 & 1200 & 6 & 174 & 6 & 183 & 4 & 130 & 5 & 145 & سنباط & 2 & 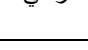 & 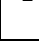 \\
\hline 136 & 11 & 340 & 5 & 165 & 15 & 495 & 65 & 2300 & 12 & 336 & 12 & 351 & 6 & 180 & 10 & 305 & & ملة & & \\
\hline 44 & 5 & 155 & 6 & 180 & 2 & 65 & 7 & 250 & 6 & 180 & 5 & 158 & 8 & 280 & 5 & 155 & الغ ابو & 1 & كفر & \\
\hline 44 & 5 & 160 & 8 & 250 & 4 & 131 & 9 & 340 & 6 & 190 & 6 & 168 & 2 & 50 & 4 & 130 & منشأه & 2 & الزيات & \\
\hline 88 & 10 & 315 & 14 & 430 & 6 & 196 & 16 & 590 & 12 & 370 & 11 & 326 & 10 & 330 & 9 & 285 & & ملة & & \\
\hline 224 & 21 & 655 & 19 & 595 & 21 & 691 & 81 & 2890 & 24 & 706 & 23 & 677 & 16 & 510 & 19 & 590 & & ي العا & الإجما & \\
\hline
\end{tabular}

المصدر : جمعت وحسبت من ملحق رقم (1) ، (2) . 
ملحق رقم (4 ) : تقدير الكفاءة الاقتصادية لمدخلات دالة إنتاج أصناف

الذرة الثامية الفردية وفقاً لعينة الدراسة بمحافظة الغربية عام2017 مانة

\begin{tabular}{|c|c|c|c|c|c|c|c|c|c|c|}
\hline الإقتصادية & (بالجنيه) & $\begin{array}{c}\text { الناتجة } \\
\text { (بالجنية) } \\
\text { الحدي }\end{array}$ & $\begin{array}{l}\text { اللداتي } \\
\text { للانصر }\end{array}$ & العنصر & $\begin{array}{c}\text { المتوسط } \\
\text { (بالأردب) }\end{array}$ & اللعنصر & $\begin{array}{l}\text { اللو غارنيمي } \\
\text { الهنسي }\end{array}$ & المتغيرات & $\begin{array}{c}\text { Y إجمالي كمية } \\
\text { الناتج بالدالة }\end{array}$ & الصنف \\
\hline$*$ & 48.32 & 241.65 & 0.537 & 0.659 & 0.815 & 30.08 & 3.4040 & $X_{1}$ & \multirow{3}{*}{$\begin{array}{c}3.1995=\mathrm{L} \\
\hat{\mathrm{Y}} \\
\\
\\
\text { أردب } 24.52)\end{array}$} & \multirow{3}{*}{ 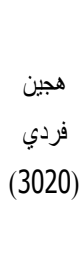 } \\
\hline * & 58.06 & 576.00 & 1.280 & 0.506 & 2.530 & 9.69 & 2.2710 & $X_{11}$ & & \\
\hline * & 7.00 & 50.85 & 0.113 & 0.033 & 3.439 & 7.13 & 1.9648 & $X_{12}$ & & \\
\hline$*$ & 67.75 & 624.6 & 1.388 & 0.374 & 3.712 & 5.63 & 1.7276 & $x_{2}$ & \multirow{3}{*}{$\begin{array}{c}3.0397=L \\
\hat{Y}\end{array}$} & \multirow{3}{*}{ فردين } \\
\hline * & 38.58 & 369.9 & 0.822 & 0.394 & 2.086 & 10.02 & 2.3044 & $X_{11}$ & & \\
\hline * & 7.38 & 30.15 & 0.067 & 0.269 & 0.248 & 84.24 & 4.4337 & $X_{13}$ & & \\
\hline$*$ & 50.14 & 42.30 & 0.094 & 0.106 & 0.884 & 27.70 & 3.3215 & $X_{1}$ & \multirow{3}{*}{$\begin{array}{c}3.1982=L \\
\hat{Y}\end{array}$} & \multirow{3}{*}{$\begin{array}{l}\text { فردين } \\
\text { هجين } \\
\text { (130) }\end{array}$} \\
\hline$*$ & 54.97 & 841.50 & 1.870 & 0.814 & 2.297 & 10.66 & 2.3669 & $X_{11}$ & & \\
\hline * & 93.05 & 661.05 & 1.469 & 0.135 & 10.884 & 2.25 & 0.8107 & $X_{15}$ & & \\
\hline$*$ & 83.85 & 230.85 & 0.513 & 0.774 & 0.663 & 37.32 & 3.6196 & $x_{2}$ & \multirow{4}{*}{$\begin{array}{c}3.2094=L \\
\hat{Y}\end{array}$} & \multirow{4}{*}{$\begin{array}{l}\text { فردين } \\
\text { هجين } \\
\text { فرين }\end{array}$} \\
\hline * & 30.00 & 399.15 & 0.887 & 0.426 & 2.081 & 11.90 & 2.4763 & $X_{11}$ & & \\
\hline$*$ & 7.99 & 54.45 & 0.121 & 0.030 & 4.019 & 6.16 & 1.8187 & $X_{12}$ & & \\
\hline * & 113.23 & 805.05 & 1.789 & 0.151 & 11.847 & 2.09 & 0.7376 & $X_{15}$ & & \\
\hline
\end{tabular}

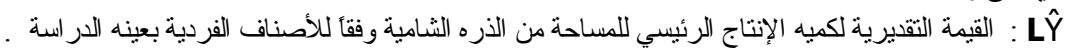




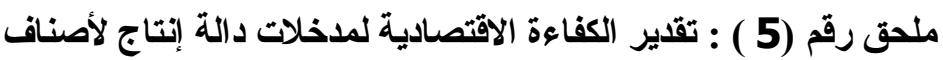

الأرة الثامية الثلاثية وفقاً لعينة الار اسةة بمحافظة الغربية 2017 م

\begin{tabular}{|c|c|c|c|c|c|c|c|c|c|c|}
\hline الإتصادية & العنصر & فلقيمة الناتج & اللغناتج & العضر & المتأنج & اللعنصر & $\begin{array}{l}\text { اللو غارتيمي } \\
\text { الوسطي }\end{array}$ & المتنيرات & $\begin{array}{c}\text { إلجمالي كمية } \\
\text { الناتج بالدالة }\end{array}$ & الصنف \\
\hline * & 47.77 & 104.85 & 0.233 & 0.275 & 0.846 & 29.81 & 3.3947 & $X_{1}$ & \multirow{5}{*}{$\begin{array}{l}3.2278=\mathrm{L} \\
\hat{Y} \\
\text { أردب }\end{array}$} & \multirow{5}{*}{ هـ بـ } \\
\hline * & 75.26 & 255.15 & 0.567 & 0.153 & 3.703 & 6.81 & 1.9180 & $x_{2}$ & & \\
\hline * & 20.09 & 445.95 & 0.991 & 0.495 & 2.003 & 12.59 & 2.5328 & $X_{11}$ & & \\
\hline$*$ & 7.37 & 92.25 & 0.205 & 0.030 & 6.835 & 3.69 & 1.3045 & $X_{12}$ & & \\
\hline * & 111.74 & 731.7 & 1.626 & 0.147 & 11.061 & 2.28 & 0.8243 & $X_{15}$ & & \\
\hline$*$ & 22.48 & 69.75 & 0.155 & 0.208 & 0.744 & 26.91 & 3.2925 & $x_{3}$ & \multirow{3}{*}{$\begin{array}{c}2.9966=L \\
\hat{Y} \\
\text { أردب } 20.02)\end{array}$} & \multirow{3}{*}{ هـ } \\
\hline * & 20.55 & 147.6 & 0.328 & 0.215 & 1.526 & 13.12 & 2.5739 & $X_{11}$ & & \\
\hline * & 6.67 & 54.9 & 0.122 & 0.607 & 0.201 & 99.51 & 4.6003 & $X_{13}$ & & \\
\hline$*$ & 20.45 & 312.3 & 0.694 & 0.364 & 1.907 & 8.95 & 2.1918 & $X_{11}$ & \multirow{2}{*}{$\begin{array}{c}2.8375=\mathrm{L} \\
\hat{Y} \\
\text { أردب } 1 \text { (17.07) }\end{array}$} & \multirow{2}{*}{ هـ (324) } \\
\hline * & 7.21 & 47.25 & 0.105 & 0.540 & 0.195 & 87.34 & 4.4698 & $X_{13}$ & & \\
\hline$*$ & 48.26 & 124.2 & 0.276 & 0.339 & 0.815 & 25.18 & 3.2262 & $x_{1}$ & \multirow{2}{*}{$\begin{array}{c}3.0221=\mathrm{L} \\
\hat{Y} \\
\text { أردب } 20.53)\end{array}$} & \multirow{2}{*}{$\begin{array}{l}\text { هـ (311) } \\
\text { (311) }\end{array}$} \\
\hline * & 19.24 & 606.15 & 1.347 & 0.755 & 1.784 & 11.51 & 2.4429 & $X_{11}$ & & \\
\hline
\end{tabular}

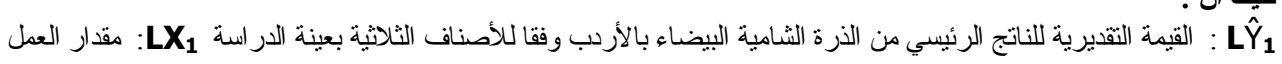
البشري بكل صنف مقاسأ رجل / بيوم.

L LX

: LX12

LX 15
LX2

الالي (ري) مقاسأ بالساعة العية

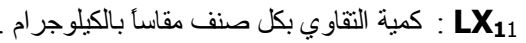

بكل صنف مقاسأ بالوحدة

LX 13 المستخدمة بكل صنف مقاسأ باللتر الإن

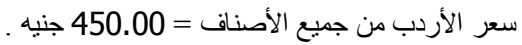

المصدر : جداول التفريغ الخاصة باستيبان العينة .

\section{التوصيات}

$$
\text { بوصي البحث الآتي: }
$$

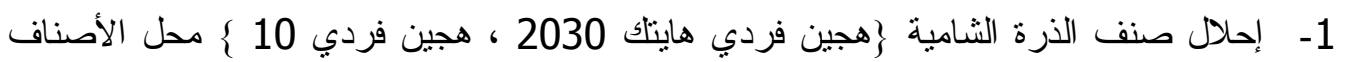

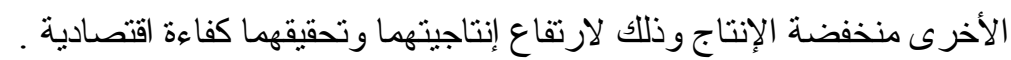

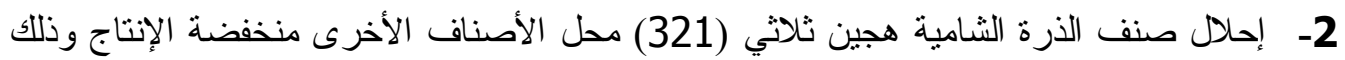

لارتفاع إنتاجيته وتحقيقه كفاءة اقتصادية .

3- يوصي بإلز ام الشركات المنتجة لنقاوي الذرة الثامية البيضاء في مصر بتتفيذ نوصيات البحث . 


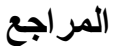

1- إبر اهيم السيد عيسي ( دكتور ) - بعض الآثار الاقتصادية لأهم الأصناف المحسنة من الذرة الثامية

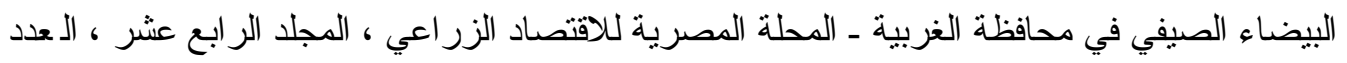

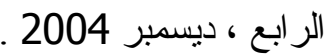

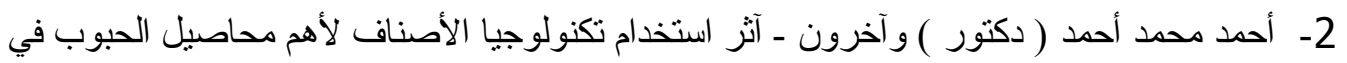

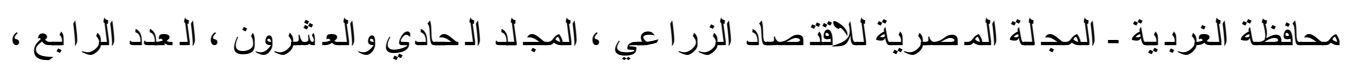
سبتمبر 2011 . 3- إيناس محمد عباس محمد صالح( دكتور ) - در اسة اقتصادية لأثر استخدام الأصناف المحسنة علي

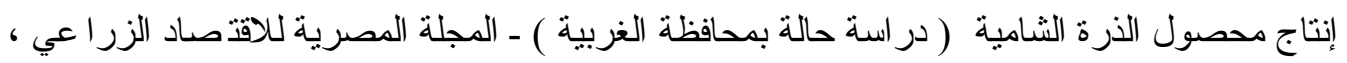
المجلد الثالث و العشرون ، العدد الثالث ، سبتمبر 2013.

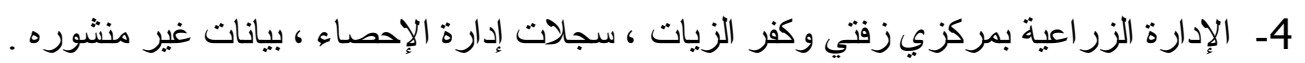

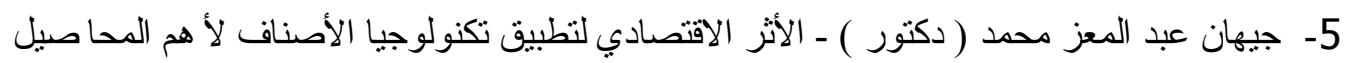

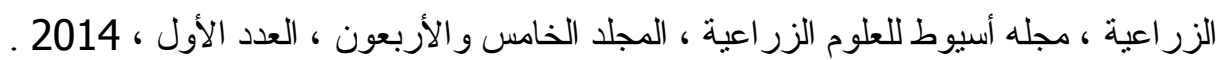

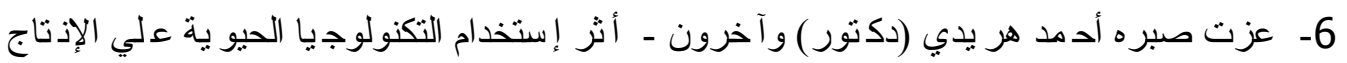

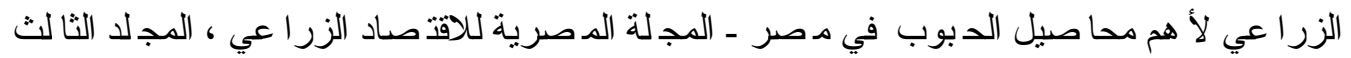

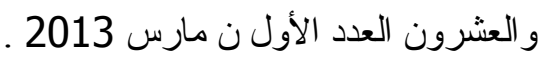

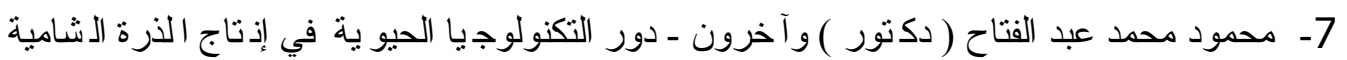

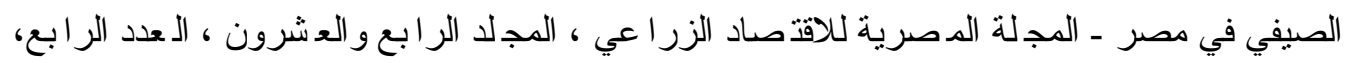
ديسمبر 2014 . 8- محي الدين مد مد خليل البيجاوي( دكتور ) ـ التوز يع الأو فق لأصناف مدصول الذرة الشامية

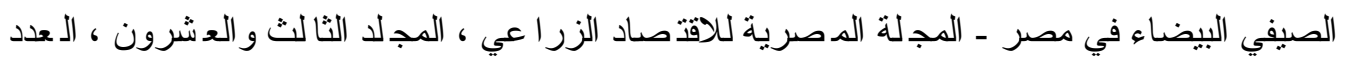
الثاني ، بونيو 2013 . 9- مديرية الزر اعة بالغربية - سجلات إدارة الإحصاء - بيانات غير منشورة .

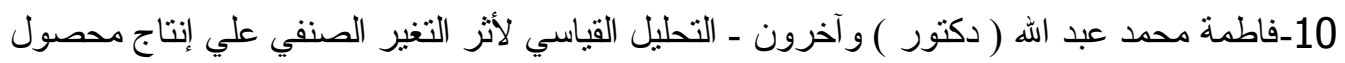

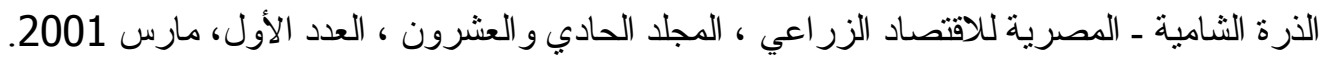

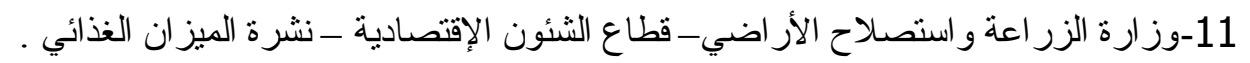
12-وزارة الزراعة واستصلاح الأراضي ، مركز البحوث الزراعية ـ معهد بحوث المحاصيل ـ الأصناف الهجين المتداولة .

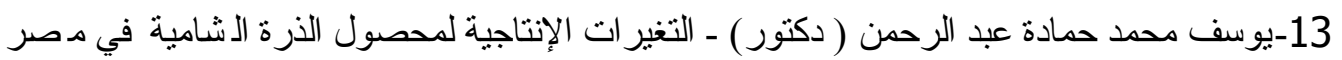

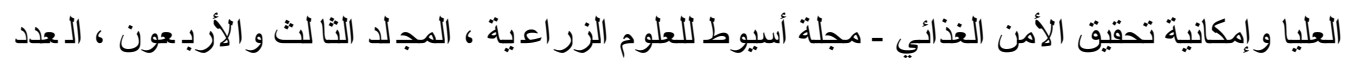
السادس ، 2012 . 14 - Harry. Ayer and G Edward Schuh, Social Rates of Return and other Aspects of Agricultural Research, The case of Cotton Research in Sao Paulo, Barazil, American Journal of Agricultural Economics Vol. 54 No 4 part 1, 1972 P . 560 . 